\title{
STRATEGI PENGEMBANGAN INFRASTUKTUR KECAMATAN CARINGIN SEBANGAI PKWP WILAYAH PUSAT PERTUMBUHAN RANCABUAYA
}

\author{
Dadan Mukhsin \\ ${ }^{1}$ Program Studi Perencanaan Wilayah dan Kota, Fakultas Teknik, \\ Universitas Islam Bandung \\ Jl. Tamansari No. 1 Bandung, 40116
}

\begin{abstract}
ABSTRAK
Infrastruktur menurut Grigg (Nurmadimah, 2012:19) adalah "semua fasilititas fisik yang sering disebut dengan pekerjaan umum”. Menurut AGCA (associated General Conctractor of America), mendefinisikan infraktruktur adalah semua aset berumur panjang yang dimiliki oleh pemerintah setempat, pemerintah daerah maupun pusat dan utilitas yang dimiliki oleh para pengusaha (Nurmadimah, 2012:20)

Maksud dan tujuan dari kegiatan pada penyusunan ini adalah menyusun strategi mengenai pengembangan infrastruktur yang disediakan di Kecamatan Caringin yang terintegrasi dengan pengembangan wilayah. Dalam penyusunan Strategi Pengembangan Infrastruktur Penunjang Wisata di Kecamatan Caringin diharapkan menghasilkan suatu kegiatan perencanaan yang terarah, maka perlu adanya panduan untuk menggambarkan tahapan-tahapan kegiatan untuk mencapai maksud dan tujuan

Strategi untuk meningkatkan keterkaitan antar kawasan pusat pertumbuhan Rancabuaya dengan daerah lainnya, meliputi: Mengembangkan pusat pariwisata bahari, Meningkatkan fungsi dan status jalan antar pusat kawasan dan Menyediakan sarana dan prasarana pendukung fungsi pusat kawasan.
\end{abstract}

Keyword : Strategi, Infratruktur, Rancabuaya

\section{Pendahuluan}

Transportasi adalah kegiatan perpindahan orang atau barang dari satu tempat (asal) ke tempat lain (tujuan) dengan menggunakan sarana kendaraan bermotor maupun tidak bermotor. Transportasi terbagi menjadi beberapa jenis yaitu transportasi darat (mobil, motor, kereta api, sepeda, dll), udara (pesawat terbang, helikopter, dll), dan laut (perahu layar, perahu dayung, kapal motor, dll). Transportasi darat merupakan jenis alat transportasi yang paling banyak digunakan oleh masyarakat karena biaya perjalanan yang jauh lebih murah dan mudah untuk digunakan baik oleh pribadi maupun umum
Infrastruktur menurut Grigg (Nurmadimah, 2012:19) adalah "semua fasilititas fisik yang sering disebut dengan pekerjaan umum". Menurut AGCA (associated General Conctractor of America), mendefinisikan infraktruktur adalah semua aset berumur panjang yang dimiliki oleh pemerintah setempat, pemerintah daerah maupun pusat dan utilitas yang dimiliki oleh para pengusaha (Nurmadimah, 2012:20)

Pengkategorian dalam program pembangunan prasarana kota terpadu (P3KT) tidak menyertakan bagunan gedung dan fasilitas rekreasi, serta memisahkan pengelolaan air bersih dengan air kotor, sedang 
Grigg maupun Hudson mengkategorikan pengelolaan air bersih, air limbah dan drainase pada satu kategori dan menyertakan serta memasukan bangunan gedung dan fasilitas rekreasi pada kategori terpisah (Nurmadimah, 2012:20). Pada gambar selanjutnya merupakan sistem infrastruktur dalam bentuk pengelompokan adalah sebagai berikut.

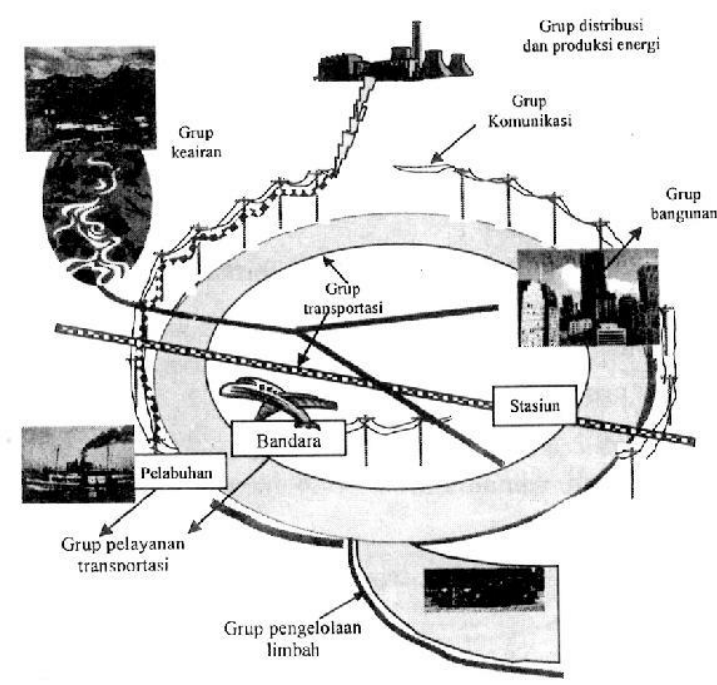

Gambar 1. Sistem Infrastruktur Dalam Pengelompokan Sumber: Grigg, 1998; Grigg \& Fontane, 2000 Dalam Kodoatie, 2005

Rencana sistem perkotaan yang tertera dalam Rencana Tata Ruang Wilayah Kabupaten Garut ditentukan berdasarkan tiga pertimbangan yakni penggunaan metode skalogram, indeks sentralitas terbobot dan fungsi serta peran kota terhadap kawasan di sekitarnya. Rencana pengembangan sistem pusat-pusat permukiman di wilayah Kabupaten Garut adalah sebagai berikut :

1. Kota dengan fungsi sebagai Pusat Kegiatan Wilayah promosi (PKWp) yaitu Rancabuaya di Kecamatan Caringin. Pusat Kegiatan Wilayah promosi (PKWp) adalah kawasan perkotaan yang berpotensi pada bidang tertentu dan memiliki pelayanan skala provinsi atau beberapa kabupaten/kota serta berperan sebagai penyeimbang dalam pengembangan wilayah provinsi.

Fasilitas minimum yang tersedia di PKWp adalah:
a. Perhubungan : Pelabuhan udara, dan/atau pelabuhan laut dan/atau terminal tipe B.
b. Ekonomi : Pasar induk regional.
c. Kesehatan : Rumah sakit umum tipe B.
d. Pendidikan : Perguruan tinggi.

\section{Maksud, Tujuan dan Sasaran}

Maksud dan tujuan dari kegiatan pada penyusunan ini adalah menyusun strategi mengenai pengembangan infrastruktur yang disediakan di Kecamatan Caringin yang terintegrasi dengan pengembangan wilayah Metodologi

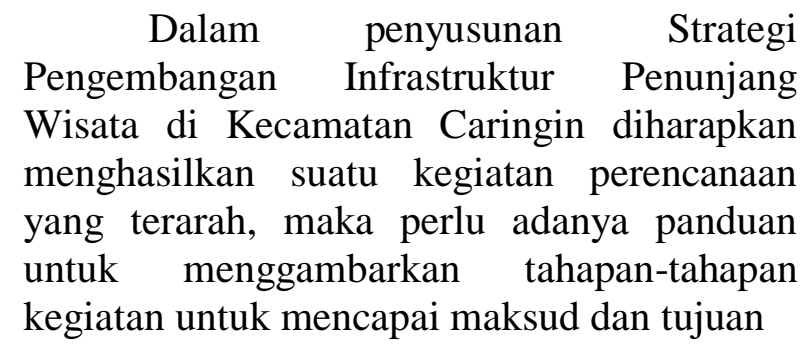

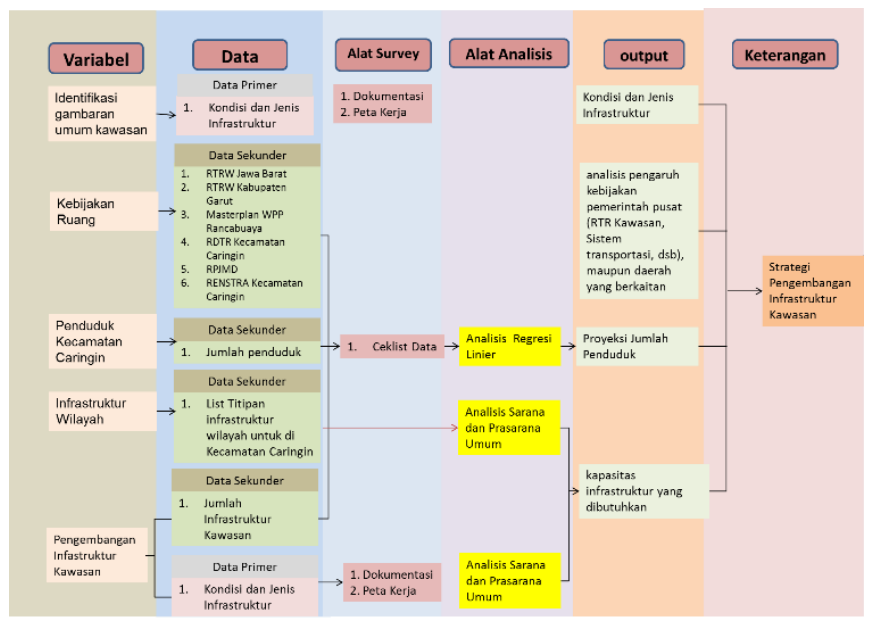

Gambar 2

Tahapan Penyelesaian

Perhitungan proyeksi jumlah penduduk menggunakan metode regresi linier karena diasumsikan perkembangan penduduk cenderung mengikuti trend (secara linier) dan pertumbuhannya positif (Suwarjoko Warpani, 1984: 44), sedangkan jumlah kunjungan wisatawan menggunakan metode polinomial dengan asumsi bahwa jumlah wisatawan terus mengalami kenaikan. Variabel yang digunakan dalam rumus ini adalah 
jumlah wisatawan yang berkunjung selama lima tahun terakhir (time series).

- Metode Regresi Linier

$$
\begin{aligned}
& \mathrm{Pt}=\mathrm{a}+\mathrm{b}(\mathrm{x}) \mathrm{a}=\frac{\Sigma \mathrm{Y}}{\mathrm{N}} \quad \mathrm{b}=\frac{\Sigma \mathrm{X} \cdot \Sigma \mathrm{Y}}{\Sigma \mathrm{X}^{2}} \\
& \text { Keterangan : } \\
& \mathrm{P}_{\mathrm{t}+\mathrm{x}} \quad=\text { Jumlah Penduduk tahun } \\
& \text { proyeksi } \\
& \mathrm{a} \text { dan } \mathrm{b} \quad=\text { konstanta } \\
& \mathrm{y} \quad=\text { Jumlah Penduduk } \\
& \mathrm{x}=\text { Indeks Tahun Proyeksi } \\
& \mathrm{N} \quad=\text { Banyaknya tahun yang dihitung } \\
& \mathrm{P}_{\mathrm{t}+\mathrm{x}} \quad=\text { Jumlah Penduduk tahun } \\
& \text { proyeksi } \\
& \mathrm{X} \quad=\text { selisih tahun proyeksi dengan } \\
& \text { tahun dasar } \\
& \mathrm{N}=\text { jumlah bilangan tahun } \\
& \mathrm{a}+\mathrm{b}=\text { konstanta } \\
& \mathrm{a}=\frac{\Sigma \mathrm{P} \Sigma \mathrm{X}^{2}-\Sigma \mathrm{X} \Sigma \mathrm{XP}}{\mathrm{N} \Sigma \mathrm{X}^{2}-\Sigma(\mathrm{x})^{2}} \quad \mathrm{~b}=\frac{N \Sigma X \cdot P-\Sigma x \Sigma P}{N \Sigma(X)^{2}}
\end{aligned}
$$

Analisis perkiraan kebutuhan air bersih ini digunakan untuk mengetahui jumlah kebutuhan masyarakat pemakai air, balk untuk kebutuhan domestik maupun kebutuhan non domestik dengan asumsi bahwa kebutuhan air bersih yang digunakan penduduk adalah 150 liter/hari. Adapun langkahlangkah dalam menghitung perkiraan kebutuhan air bersih ini adalah : (Sumber :

- Kebutuhan domestik (debit)

$$
Q_{D}=\text { Jumlah pemakai } x \text { standar }
$$
kebutuhan

- Kebutuhan non domestik

$$
Q_{N D}=\text { Jumlah Fasilitas } x \text { standar }
$$
kebutuhan / unit

- Kebutuhan harian rata-rata

$$
Q_{R}=Q_{D}+Q_{N D}
$$

- Kehilangan air

$$
Q_{H}=(40 \%) X Q_{R}
$$

- Kebutuhan total Produksi rata-rata

$$
\text { Qprod }=Q_{D}+Q_{N D}+Q_{H}
$$

Kebutuhan air tanaman meliputi jumlah air yg digunakan untuk pemakaian konsumtif (ET) dan air yg hilang melalui perkolasi. Kebutuhan air pada tingkat usaha tani biasa disebut Agrohidrologi yaitu perhitungan didasarkan pada data agroklimat, yaitu data kebutuhan tanaman akan air dalam hubungannya dengan lingkungan iklim dan tanah

Satuan $=\mathrm{mm} /$ hari atau $\mathrm{m} 3 /$ hari/ha atau $\mathrm{lt} / \mathrm{dt} / \mathrm{ha}$

\section{Cara Menghitung}

$\mathrm{Q} 1=\mathrm{H} \times \mathrm{A} / \mathrm{T} \times 10.000$

$\mathrm{Q} 1=$ kebutuhan air irigasi (1t/dt/ha)

$\mathrm{H}=$ ketebalan air/tinggi genangan $(\mathrm{m} / \mathrm{hari})$

$\mathrm{A}=$ luas areal (ha)

$\mathrm{T}=$ lama pemberian air (hari atau detik)

Menghitung aksesibilitas dan sistem gravitasi dari tiap desa dengan memperhitungkan kualitas jalan, jarak antar desa, dan jumlah penduduk yang ada di Kecamatan Caringin

Rumus perhitungan Aksesibilitas=

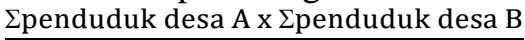
jarak antar desa ${ }^{\mathrm{n}}$

Rumus Perhitungan Gravitasi= 9,8[ $\left[\frac{\text { penduduk desa A x } \Sigma \text { penduduk desa B }}{\text { jarak antar desa }^{\mathrm{n}}}\right]$

Keterangan :

$\mathrm{n}=$ kualitas jalan

Untuk memperkirakan kebutuhan listrik di Kawasan Rancabuaya pada akhir tahun perencanaan dihitung berdasarkan standar dan asumsi kebutuhan listrik di daerah perkotaan. Perkiraan kebutuhan energi listrik direncanakan dengan menggunakan beberapa kriteria sebagai berikut :

- Jumlah Rumah Tangga dengan asumsi 1 Rumah Tangga/KK terdapat 5 orang

- Standar kebutuhan 1 rumah tangga 900 Watt Rumus Proyeksi Kebutuhan Listrik : Sumber : Perhitungan Listrik, $=$

$\frac{\Sigma \text { penduduk }}{5} x$ Standar Penggunaan Daya (watt) / rumah/kk (900 Watt)

\section{Hasil dan Analisis}

Secara umum pertimbanganpertimbangan dalam melakukan proyeksi penduduk (termasuk didalamnya memilih metode/metode proyeksi) kawasan perencanaan antara lain:

1. Perkembangan jumlah penduduk

2. Kepadatan penduduk

3. Ketersediaan lahan 
Untuk lebih jelasnya proyeksi penduduk dari tahun 2014-2034 dapat dilihat pada tabel berikut:

Tabel 1

Proyeksi Penduduk Kawasan Pusat Pertumbuhan Rancabuaya Tahun 2014-2034

\begin{tabular}{|c|c|c|c|c|c|c|c|}
\hline \multirow{2}{*}{$\begin{array}{l}\mathrm{N} \\
\mathrm{o}\end{array}$} & \multirow[t]{2}{*}{ Desa } & \multirow{2}{*}{$\begin{array}{l}\text { Luas } \\
\text { Wila } \\
\text { yah } \\
\text { (Ha) }\end{array}$} & \multirow{2}{*}{$\begin{array}{c}\text { Jml. Pddk } \\
\text { Tahun } \\
2014\end{array}$} & \multicolumn{4}{|c|}{ Jumlah Penduduk (Jiwa) } \\
\hline & & & & 2019 & 2024 & 2029 & 2034 \\
\hline 1 & $\begin{array}{l}\text { Carin } \\
\text { gin }\end{array}$ & 9.903 & 34.729 & $\begin{array}{r}35.99 \\
3\end{array}$ & $\begin{array}{r}37.30 \\
3\end{array}$ & $\begin{array}{r}38.66 \\
0\end{array}$ & $\begin{array}{r}40.06 \\
7\end{array}$ \\
\hline 2 & $\begin{array}{l}\text { Cise } \\
\text { wu }\end{array}$ & 9.483 & 40.876 & $\begin{array}{r}42.83 \\
2\end{array}$ & $\begin{array}{r}44.88 \\
1\end{array}$ & $\begin{array}{r}47.02 \\
9\end{array}$ & $\begin{array}{r}49.27 \\
9\end{array}$ \\
\hline 3 & $\begin{array}{l}\text { Bung } \\
\text { bulan } \\
\mathrm{g}\end{array}$ & $\begin{array}{r}13.44 \\
4\end{array}$ & 69.493 & $\begin{array}{r}74.35 \\
2\end{array}$ & $\begin{array}{r}79.55 \\
1\end{array}$ & $\begin{array}{r}85.11 \\
3\end{array}$ & $\begin{array}{r}91.06 \\
4\end{array}$ \\
\hline 4 & $\begin{array}{l}\text { Meka } \\
\text { rmuk } \\
\text { ti }\end{array}$ & 5.522 & 18.991 & $\begin{array}{r}19.48 \\
0\end{array}$ & $\begin{array}{r}19.98 \\
2\end{array}$ & $\begin{array}{r}20.49 \\
7\end{array}$ & $\begin{array}{r}21.02 \\
5\end{array}$ \\
\hline 5 & $\begin{array}{l}\text { Cida } \\
\text { un }\end{array}$ & $\begin{array}{r}32.30 \\
3 \\
\end{array}$ & 63.323 & $\begin{array}{r}63.16 \\
1 \\
\end{array}$ & $\begin{array}{r}62.99 \\
9 \\
\end{array}$ & $\begin{array}{r}62.83 \\
8 \\
\end{array}$ & $\begin{array}{r}62.67 \\
7 \\
\end{array}$ \\
\hline & nlah & $\begin{array}{r}70.65 \\
5,00\end{array}$ & 227.412 & $\begin{array}{r}235.8 \\
18\end{array}$ & $\begin{array}{r}244.7 \\
16\end{array}$ & $\begin{array}{r}254.1 \\
37\end{array}$ & $\begin{array}{r}264.1 \\
13\end{array}$ \\
\hline
\end{tabular}

Sumber: Hasil Analisis, 2014

Proyeksi kepadatan penduduk tahun 20142034 di Kawasan Pusat Pertumbuhan Rancabuayadapat dilihat pada tabel berikut:

Tabel 2

Proyeksi Kepadatan Penduduk Pusat Pertumbuhan Rancabuaya Tahun 2014-2034

\begin{tabular}{|lccr|}
\hline \multicolumn{1}{|c}{ Tahun } & 2014 & 2019 & 20 \\
\hline Juas Wilayah (Ha) & $70.655,00$ & $70.655,00$ & 70.6 \\
\hline Kepadatan Penduduk (Jiwa) & 227.412 & 235.818 & 244 \\
\hline Sumber: Hasil Analisis, 2014 & 3 & 3 & \\
\hline
\end{tabular}

Analisis struktur ruang di Kawasan

Pusat

Pertumbuhan

Rancabuayapenyebarannya diarahkan pada kawasan-kawasan budidaya dimana kondisi eksisting telah terbangun. Disamping itu untuk kegiatan-kegiatan utama, penyebarannya diarahkan pada tempat-tempat strategis atau yang mempunyai aksesibilitas baik, sehingga mudah dijangkau dari seluruh kawasan. Kegiatan utama yang akan dikembangkan di pusat pelayanan ini berupa jasa pelayanan kegiatan pemerintahan, jasa pelayanan sarana sosial dan umum, dan jasa pelayanan perdagangan dan jasa, yang dikembangkan secara berjenjang sesuai skala pelayanannya. Hirarki pusat pelayanan yang akan dikembangkan secara berjenjang dan terpadu sesuai skala pelayanannya dapat dilihat pada tabel berikut :
Tabel 3

Analisis Struktur Ruang Kawasan Pusat Pertumbuhan Rancabuaya

\begin{tabular}{|c|c|}
\hline Kecamatan & Fungsi \\
\hline Caringin & $\begin{array}{l}\text { - Pusat pengembangan kegiatan } \\
\text { Regional (sebagai PKWp) } \\
\text { - } \text { Pusat pengembangan kawasan } \\
\text { pemerintahan } \\
\text { - } \text { Pusat Pengembangan Pariwisata } \\
\text { terpadu } \\
\text { - Pusat Pengembangan Sarana } \\
\text { Peribadatan (Islamic Centre) } \\
\text { - Rencana pengembangan } \\
\text { kelengkapan fasilitas sosek } \\
\text { - Rencana Terminal Tipe B } \\
\text { Koleksi dan distribusi hasil } \\
\text { perikanan. }\end{array}$ \\
\hline Mekarmukti & 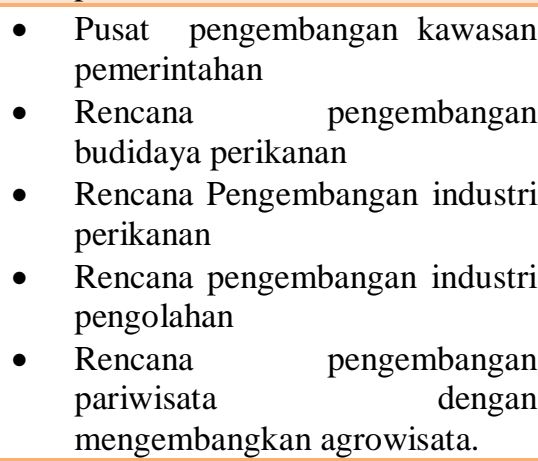 \\
\hline Cisewu & $\begin{array}{l}\text { - } \text { Pengembangan Taman Buru } \\
\text { Budidaya Pertanian Dan } \\
\text { Perkebunan } \\
\text { Rencana Pengembangan } \\
\text { Terminal Tipe C } \\
\text { Rencana Pembangunan Pasar } \\
\text { Tradisional Berdampingan } \\
\text { Dengan Terminal } \\
\text { Pengembangan Jalan Arteri } \\
\text { Primer }\end{array}$ \\
\hline Bungbulang & 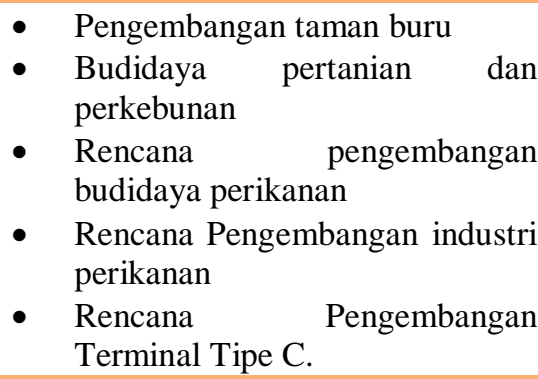 \\
\hline Cidaun & $\begin{array}{l}\text { - } \\
\text { - } \\
\text { - } \\
\text { - } \\
\text { Kengengembangan wisata pelabuhan } \\
\text { Keleksi dan distribusi hasil } \\
\text { - } \quad \text { Rencananan } \\
\text { perikanan. }\end{array}$ \\
\hline
\end{tabular}

Sumber: Hasil Analisis, 2014 
Perkiraan kebutuhan permukiman di Kawasan Pusat Pertumbuhan Rancabuaya menggunakan pendekatan penyediaan perumahan berdasarkan jumlah penduduk di akhir tahun dengan perbandingan penyediaan perumahan berdasarkan tipe kecil: sedang: besar adalah 1:2:3. Rumah tipe kecil dengan luas $90 \mathrm{~m}^{2}$, tipe sedang $180 \mathrm{~m}^{2}$, dan tipe besar $360 \mathrm{~m}^{2}$, dengan asumsi 1 keluarga adalah 5 orang. Total kebutuhan rumah di Kawasan Pusat Pertumbuhan Rancabuaya pada akhir tahun perencanaan sebanyak 52.823 unit dengan luas total $2.641 \mathrm{Ha}$. Untuk mengetahui lebih jelas perkiraan kebutuhan permukiman tahun 2034 dapat dilihat pada Tabel berikut.

Tabel 4

Proyeksi Kebutuhan Perumahan Di Kawasan Pusat Pertumbuhan Rancabuaya

Tahun 2034

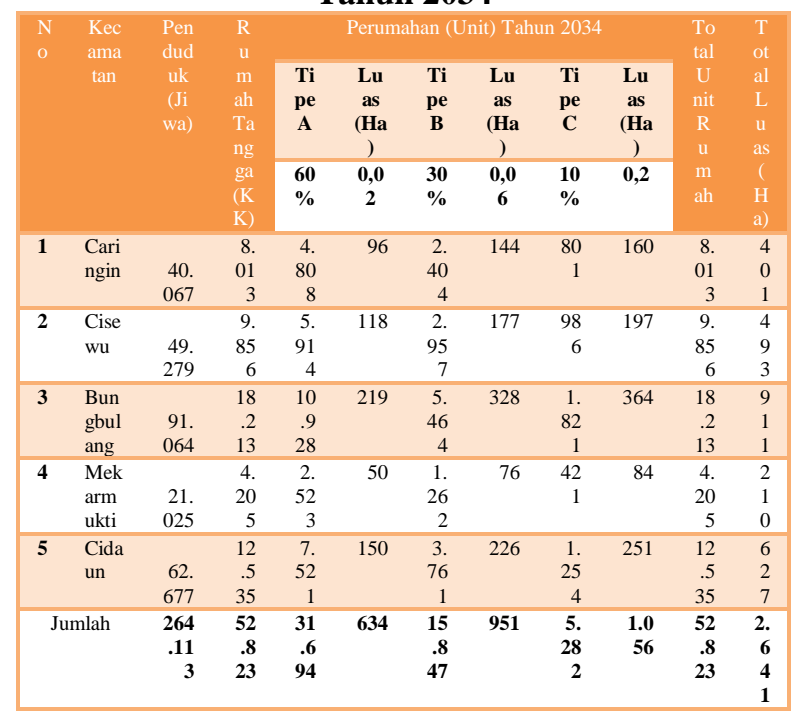

Sumber: Hasil Analisa, 2014

Berbagai potensi wisata yang terdapat di kawasan pertumbuhan Rancabuaya dapat dikelompokkan ke dalam beberapa blok dengan tema pengembangan yang berbeda. Ada empat blok kawasan pariwisata yang dapat dikembangkan dengan blok Rancabuaya sebagai kawasan pariwisata inti dan blok Jayanti, blok Cisewu, serta blok Mekarmukti-Bungbulang sebagai kawasan pariwisata alternatif.

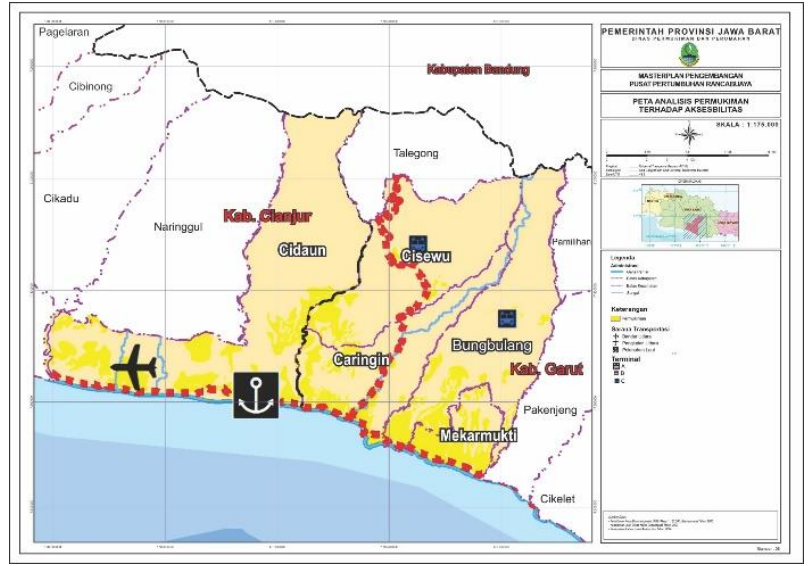

Gambar 3

Peta Analisis Permukiman Terhadap

Aksesibilitas

\section{Pembagian Blok}

Blok Rancabuaya diposisikan sebagai blok inti pariwisata dengan tema wisata pantai dan wisata budaya. Lokasi, aksesibilitas, serta kondisi topografi tapak mendukung pengembangan blok ini. Blok Jayanti dengan pangkalan pendaratan ikan, pantai, dan hutan cagar alamnya menawarkan alternatif wisata yang menarik. Kondisi saat ini yang relatif lebih ramai dari kawasan blok Rancabuaya menuntut adanya integrasi agar pengembangan yang dilakukan dapat berjalan selaras.

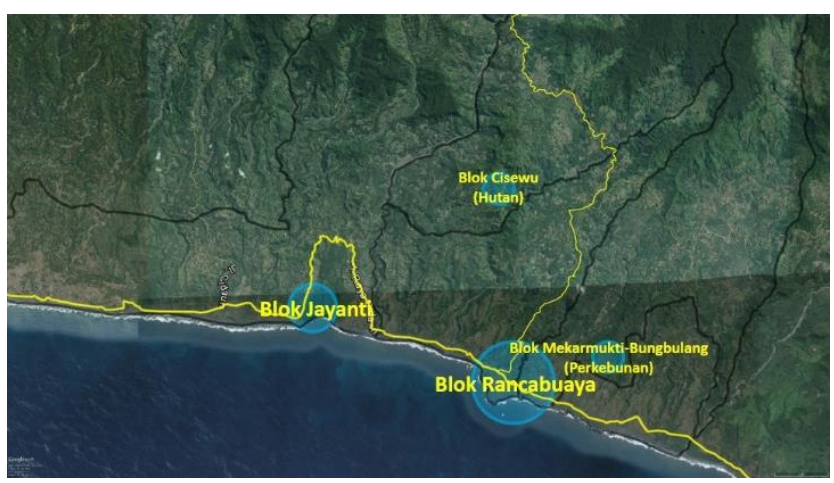

Gambar 4. Pembagian Blok Pariwisata Pusat Pertumbuhan Rancabuaya

Berdasarkan gambar pembagin blok diatas, dapat diketahui bahwa di kawasan pusat pertumbuhan Rancabuaya terdapat beberapa pembagian blok sesuai dengan tema wisata yang akan dikembangkan, pembagian blok tersebut antara lain :

1. Blok Rancabuaya (Inti);

2. Blok Jayanti;

3. Blok Mekarmukti-Bugbulang; dan

4. Blok Cisewu. 
Sebagai gerbang menuju Rancabuaya melalui jalur akses vertikal Jawa Barat, blok Cisewu menawarkan nuansa yang berbeda karena tidak memiliki pantai melainkan hutan. Tema wanawisata menjadi tema yang akan dikembangkan pada blok ini. Pada blok Mekarmukti-Bungbulang tema yang akan dikembangkan adalah agrowisata sebagai upaya untuk mengintegrasikan potensi perkebunan kawasan pusat pertumbuhan Rancabuaya dengan kegiatan pariwisata. Disamping itu blok ini akan dipersiapkan untuk pengembangan fungsi pemerintahan dan pendidikan.

\section{a. Blok Rancabuaya}

Perpresktik pengembangan Blok Rancabuaya adalah sebagai berikut :

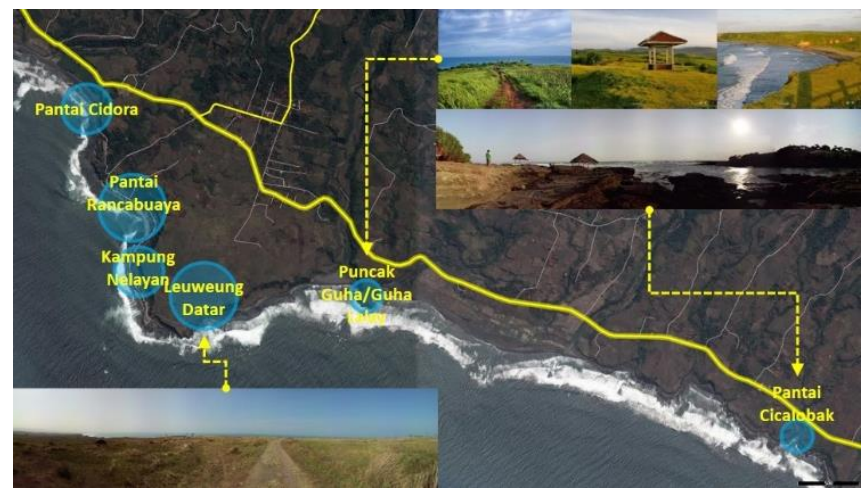

Gambar 5

Objek wisata blok Rancabuaya 1

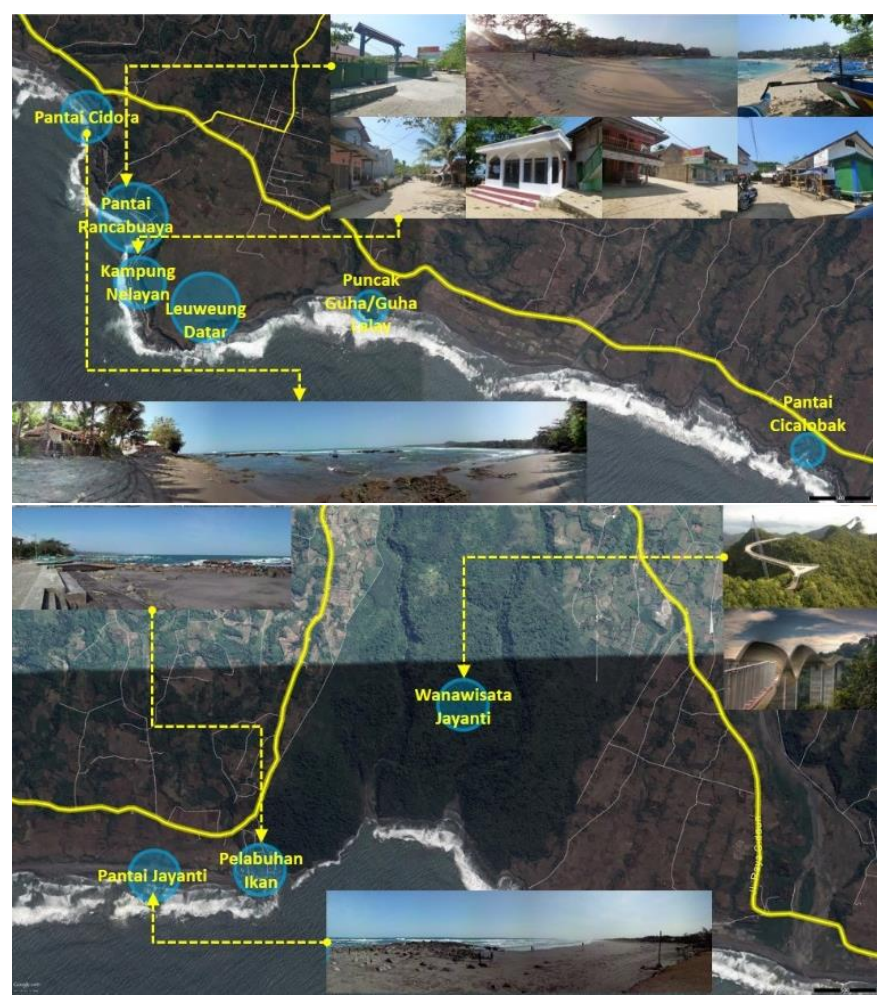

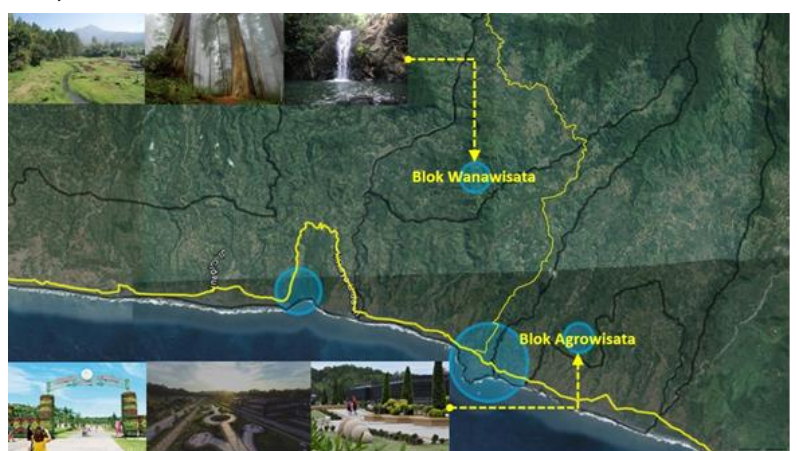

Gambar 6

Blok Wanawisata Dan Agrowisata

2. Pengembangan Infrastruktur Transportasi

Pengembangan infrastruktur transportasi bertumpu pada dua aspek, konektivitas dan mobilitas. Konektivitas meliputi pengembangan transportasi antara kawasan pusat pertumbuhan Rancabuaya dengan daerah lainnya. Hal yang menjadi fokus adalah arus orang dan barang dari dan ke Rancabuaya. Tanggungjawab pengembangan aspek konektivitas ini ada pada pemerintah terutama untuk menyediakan infrastruktur jalan beserta sistem dan moda transportasinya.

Mobilitas menjadi hal yang juga krusial bagi kawasan Rancabuaya untuk menunjang pergerakan dalam kawasan. Objek wisata yang banyak terdapat dalam kawasan jika dihubungkan dengan sistem mobilitas internal yang baik akan menjadi nilai tambah bagai pengembangan pariwisata kawasan dan meningkatkan daya saing dengan kawasan tujuan wisata lainnya. Sektor mobilitas dapat diupayakan melalui kerjasama dengan pihak swasta secara terintegrasi dalam kegiatan wisata

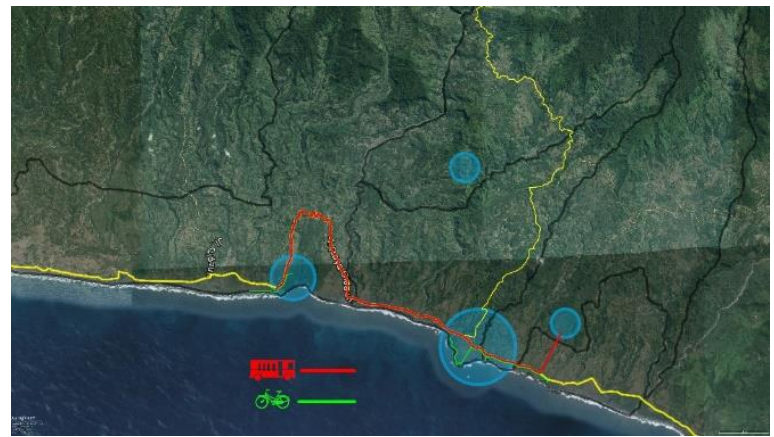

Gambar 7

Pengembangan Infrastruktur Transportasi 


\section{Pengembangan Infrastruktur Transportasi}

Salah satu penunjang utama pariwisata adalah fasilitas penginapan. Terdapat berbagai jenis fasilitas penginapan dengan perbedaan segmen pengguna, mulai dari penginapan di rumah warga, hotel melati, hotel berbintang, hingga resor. Diversifikasi penginapan perlu dilakukan untuk memperluas jangkauan segmen wisatawan kawasan Rancabuaya ini. Untuk jangka pendek dan menengah bisa dibangun hotel-hotel sederhana serta menata penginapan yang dibuka dipermukiman warga untuk melayani segmen wisatawan lokal sampai nusantara. Untuk jangka panjang perlu dikembangkan penginapan tipe resor hingga kelas mewah sebagai akomodasi bagi wisatawan dengan kelas yang lebih tinggi baik lokal maupun mancanegara.

Arahan pengembangan penginapan yang diberikan dipengaruhi oleh pola ruang kawasan. Blok hotel diarahkan untuk dibangun di kawasan yang didorong untuk memiliki kepadatan penduduk lebih tinggi yaitu ke arah timur dari blok Rancabuaya sampai ke kawasan pusat pemerintahan di Kecamatan Mekarmukti. Sedangkan blok resor diarahkan pada sisi barat blok Rancabuaya yang diatur agar lebih rendah dari sisi kepadatan penduduk, lebih terpencil, serta memiliki nuansa kawasan lindung yang lebih

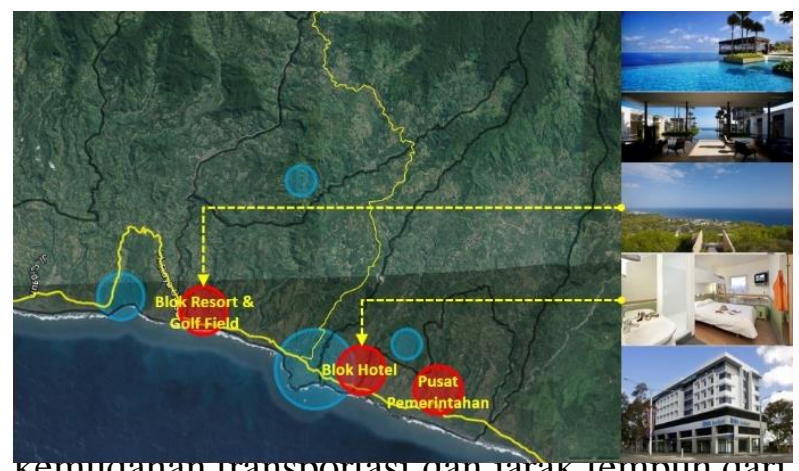

kemuaanan transportast aan jarak tempun darl ibu kota negara. Provinsi Jawa Barat memiliki berbagai macam objek wisata dengan berbagai daya tarik tersendiri seperti pegunungan, pantai, marga satwa dan lain sebagainya. Kota Bandung yang merupakan ibu kota dari provinsi Jawa Barat memiliki kekayaan alam yang bisa menarik wisatawan dengan menyajikan berbagai jenis tempat pariwisata diantaranya: Kebun Binatang, Gunung
Tangkuban Perahu, Kawah Putih, taman bunga dan pemandian Air Panas Ciater. Berikut ini disajikan pertumbuhan kunjungan wisatawan ke objek yang ada di Jawa Barat sejak Tahun 2012 sampai dengan 2015 dalam Tabel 5

\section{Tabel 5}

\section{Jumlah Kunjungan Wisatawan ke Jawa} Barat Tahun 2012-2015 Tahun

\begin{tabular}{|c|c|c|c|}
\hline & Wisman & Winus & $\begin{array}{c}\text { Jumlah } \\
\text { Wisatawan }\end{array}$ \\
\hline 2012 & 168.532 & 8.308 .485 & 8.477 .017 \\
\hline 2013 & 232.824 & 9.411 .233 & 9.644 .057 \\
\hline 2014 & 287.158 & 10.512 .315 & 10.799 .473 \\
\hline 2015 & 353.131 & 12.211 .082 & 12.564 .213 \\
\hline
\end{tabular}

Kabupaten Garut sebagai salah satu kabupaten di Provinsi Jawa Barat yang memiliki beragam objek wisata dan daya tarik wisata alam yang sangat melimpah dan indah memiliki daya tarik wisata antara lain: wisata wisata seni dan budaya, wisata sejarah, wisata alam, wisata olahraga, wisata belanja, dan wisata rohani serta kerajinan. Berikut ini disajikan pertumbuhan kunjungan wisatawan ke objek yang ada di Kabupaten Garut sejak Tahun 2010 sampai dengan 2014, pada tabel

Tabel 6

Pertumbuhan Kunjungan Wisatawan ke Objek Wisatadi Kabupaten Garut

\begin{tabular}{|c|c|c|c|}
$\begin{array}{c}\text { Tahun } \\
\mathbf{2 0 1 2} \\
\mathbf{2 0 1 6} \\
\text { Tahun }\end{array}$ & $\begin{array}{c}\text { Wisatawan } \\
\text { Manca } \\
\text { negara } \\
\text { (Orang) }\end{array}$ & $\begin{array}{c}\text { Wisatawan } \\
\text { Domestik } \\
\text { (Orang) }\end{array}$ & $\begin{array}{c}\text { Jumlah } \\
\text { Wisatawan } \\
\text { (Orang) }\end{array}$ \\
$\mathbf{2 0 1 2}$ & 4.267 & 1.352 .881 & 1.357 .148 \\
$\mathbf{2 0 1 3}$ & 4.308 & 1.421 .388 & 1.425 .696 \\
$\mathbf{2 0 1 4}$ & 4.729 & 1.574 .797 & 1.579 .526 \\
$\mathbf{2 0 1 5}$ & 6.487 & 1.789 .879 & 1.796 .366 \\
$\mathbf{2 0 1 6}$ & 5.559 & 1.645 .354 & 1.650 .913 \\
\hline Sumber : Dinas Kebudayaan dan Pariwisata \\
Kabupaten Garut 2015 (data diolah)
\end{tabular}

Berikut ini disajikan pertumbuhan beberapa objek wisata yang memiliki tingkat kunjungan wisatawan tertinggi di Kabupaten Garut :

Tabel 7

Jumlah Kunjungan Wisatawan pada Beberapa Objek Wisata

\begin{tabular}{|l|c|c|c|}
$\begin{array}{c}\text { Se Kabupaten } \\
\text { Garut tahun } \\
\text { 2012-2016 } \\
\text { Objek Wisata }\end{array}$ & \multicolumn{2}{|c|}{$\begin{array}{c}\text { Jumlah } \\
\text { Pengunjung } \\
\text { (orang) }\end{array}$} & $\begin{array}{c}\text { Laju } \\
\text { Pertumbuhan }\end{array}$ \\
\hline $\begin{array}{l}\text { Kawasan Wisata } \\
\text { Cipanas }\end{array}$ & 495.467 & 443.599 & $\mathbf{2 0 1 6}$
\end{tabular}




\begin{tabular}{|c|c|c|c|}
\hline $\begin{array}{l}\text { Pantai } \\
\text { Rancabuaya }\end{array}$ & 190.886 & 203.499 & $6,20 \%$ \\
\hline Situ Bagendit & 238.451 & 257.432 & $7,37 \%$ \\
\hline Situ Cangkuang & 154.875 & 168.791 & $8,24 \%$ \\
\hline
\end{tabular}

Berdasarkan tabel 7 dapat dilihat pertumbuhan kunjungan wisatawan ke beberapa objek wisata di kabupaten Garut selama periode tahun 2012-2016. Dalam tabel tersebut dapat terlihat bahwa objek wisata Cipanas menjadi objek wisata unggulan namun pada tahun 2015 2016 cenderung mengalami penurunan. Jumlah kunjungan ke cipanas pada tahun 2014 sebesar 495.467 namun pada tahun 2016 menurun menjadi sebesar 443.599 atau menurun sebesar 11,29\%. Berbeda dengan beberapa objek wisata lainnya seperti Pantai Santolo yang mengalami peningkatan, jumlah pengunjung ke Pantai Rancabuaya pada tahun 2015 adalah sebesar 190.886 pada tahun 2016 sebesar 203.499 atau meningkat sebesar 6,20\%.

\section{Analisis Kebutuhan Prasarana}

\section{Air Bersih}

Air bersih adalah air yang telah memenuhi syarat kesehatan baik ditinjau dari syarat kualitas, maupun kuantitas. Air bersih digunakan untuk keperluan rumah tangga (domestik) dan non rumah tangga (non domestik). Keperluan domestik seperti: minum, mencuci, masak, siram tanaman, dll. Sedangkan keperluan non domestik seperti: kegiatan perkantoran, niaga, pendidikan, peribadatan, rumah sakit, rekreasi dll.

Penggunaan air bersih di Kawasan Pusat Pertumbuhan Rancabuaya masih berasal dari sumur yang terdapat di rumah-rumah penduduk dengan kedalaman $5-10 \mathrm{~m}$, sedangkan sebagian telah dialiri air bersih perpipaan pedesaan sepanjang $8 \mathrm{~km}$ yang sumber air berasal dari Cigadog, Sungai cihideung, Sungai cipancong, sungai CisadeaCibareno, Gunung Herang, Gn Pasir Angin. Tetapi permasalahan yang ada yaitu belum semua wilayah dapat menggunakan air bersih terlayani air bersih dengan sistem perpipaan.

Agar kebutuhan air bersih dimasa datang dapat terakomodir, baik menyangkut wilayah pelayanan maupun kapasitasnya, maka perhitungan perlu dilakukan secara cermat dan matang. Untuk itu perkiraan kebutuhan air bersih akan didasarkan pada standar yang berlaku dari Direktorat Pekerjaan Umum

Tabel 8

Kriteria Perkiraan Kebutuhan Air Bersih Berdasarkan Status Kota

\begin{tabular}{|c|c|c|c|c|c|c|c|}
\hline \multirow{2}{*}{$\begin{array}{l}\mathrm{N} \\
\mathrm{o}\end{array}$} & \multirow[t]{2}{*}{ Uraian } & \multirow[t]{2}{*}{ Satuan } & \multicolumn{5}{|c|}{ Status Kota } \\
\hline & & & $\begin{array}{l}\text { Me } \\
\text { tro }\end{array}$ & $\begin{array}{c}\text { Be } \\
\text { sar }\end{array}$ & $\begin{array}{l}\text { Sed } \\
\text { ang }\end{array}$ & $\begin{array}{c}\text { Ke } \\
\text { cil }\end{array}$ & $\begin{array}{c}\text { De } \\
\text { sa }\end{array}$ \\
\hline 1 & $\begin{array}{l}\text { Konsu } \\
\text { msi unit } \\
\text { SR }\end{array}$ & $\begin{array}{l}\text { Liter/or } \\
\text { g/hari }\end{array}$ & 190 & $\begin{array}{c}17 \\
0\end{array}$ & 150 & 130 & 30 \\
\hline 2 & $\begin{array}{l}\text { Konsu } \\
\text { msi unit } \\
\text { HU }\end{array}$ & $\begin{array}{c}\text { Liter/or } \\
\text { g/hari }\end{array}$ & 30 & 30 & 30 & 30 & 30 \\
\hline 3 & $\begin{array}{l}\text { Konsu } \\
\text { msi } \\
\text { Unit } \\
\text { Non } \\
\text { Domest } \\
\text { ik*) }\end{array}$ & $\%$ & $\begin{array}{c}20- \\
30\end{array}$ & $\begin{array}{c}20 \\
- \\
30\end{array}$ & $\begin{array}{c}20- \\
30\end{array}$ & $\begin{array}{c}20 \\
- \\
30\end{array}$ & $\begin{array}{c}20 \\
- \\
30\end{array}$ \\
\hline 4 & $\begin{array}{l}\text { Kehilan } \\
\text { gan Air }\end{array}$ & $\%$ & $\begin{array}{c}20- \\
30\end{array}$ & $\begin{array}{c}20 \\
- \\
30\end{array}$ & $\begin{array}{c}20- \\
30\end{array}$ & $\begin{array}{c}20 \\
- \\
30\end{array}$ & $\begin{array}{c}20 \\
- \\
30\end{array}$ \\
\hline 5 & $\begin{array}{l}\text { Faktor } \\
\text { Maksim } \\
\text { um Day }\end{array}$ & - & 1,1 & 1,1 & 1,1 & 1,1 & 1,1 \\
\hline 6 & $\begin{array}{l}\text { Faktor } \\
\text { Peak } \\
\text { Hour }\end{array}$ & - & 1,5 & 1,5 & 1,5 & 1,5 & 1,5 \\
\hline 7 & $\begin{array}{l}\text { Jumlah } \\
\text { jiwa per } \\
\text { SR }\end{array}$ & Jiwa & 5 & 5 & 5 & 5 & 5 \\
\hline 8 & $\begin{array}{l}\text { Jumlah } \\
\text { Jiwa } \\
\text { per HU }\end{array}$ & Jiwa & 100 & $\begin{array}{c}10 \\
0\end{array}$ & 100 & 100 & $\begin{array}{c}10 \\
0\end{array}$ \\
\hline 9 & $\begin{array}{l}\text { Sisa } \\
\text { Tekan } \\
\text { di } \\
\text { Jaringa } \\
\text { n } \\
\text { Distribu } \\
\text { si }\end{array}$ & Mka & 10 & 10 & 10 & 10 & 10 \\
\hline $\begin{array}{l}1 \\
\mathbf{0}\end{array}$ & $\begin{array}{l}\text { Jam } \\
\text { Operasi }\end{array}$ & Jam & 24 & 24 & 24 & 24 & 24 \\
\hline $\begin{array}{l}1 \\
1\end{array}$ & $\begin{array}{l}\text { Volume } \\
\text { Reservo } \\
\text { ir dari } \\
\text { maxday } \\
\text { demand }\end{array}$ & $\%$ & 20 & 20 & 20 & 20 & 20 \\
\hline $\begin{array}{l}1 \\
2\end{array}$ & $\begin{array}{l}\text { Perband } \\
\text { ingan } \\
\mathrm{SR} / \mathrm{HU}\end{array}$ & - & $\begin{array}{l}50: \\
50- \\
80: \\
20\end{array}$ & $\begin{array}{c}50: \\
50 \\
- \\
80: \\
20\end{array}$ & $\begin{array}{c}80: 2 \\
0\end{array}$ & $\begin{array}{c}70 \\
: 30\end{array}$ & $\begin{array}{l}\text { 70: } \\
30\end{array}$ \\
\hline $\begin{array}{l}\mathbf{1} \\
\mathbf{3}\end{array}$ & $\begin{array}{l}\text { Cakup } \\
\text { an } \\
\text { pelaya } \\
\text { nan }\end{array}$ & $\%$ & $\begin{array}{c}90 \\
* *)\end{array}$ & $\begin{array}{l}90 \\
* *)\end{array}$ & $\begin{array}{c}90 \\
* *)\end{array}$ & $\begin{array}{l}90 \\
* *)\end{array}$ & $\begin{array}{l}\mathbf{7 0} \\
* * \\
*)\end{array}$ \\
\hline
\end{tabular}

Sumber : Direktorat Pekerjaan Umum, Jabar, 1990

Keterangan: *) tergantung survey sosek **) $60 \%$ perpipaan, $30 \%$ non perpipaan

***) $25 \%$ perpipaan, $45 \%$ non perpipaan 
Berdasarkan perhitungan proyeksi penduduk, sampai tahun 2034, Kawasan Pusat Pertumbuhan Rancabuayatermasuk kedalam kategori Kota Sedang. Dengan demikian komponen perhitungan perkiraan kebutuhan air bersih akan didasarkan pada hal-hal sebagai berikut :

- Tingkat pelayanan, Pelayanan terhadap penduduk direncanakan meningkat per 5 tahun perencanaan. Direncanakan sampai tahun 2014, tingkat pelayanan $36 \%$ (mendekati eksisting) meningkat $50 \%$ sampai tahun 2019, dan pada tahun 2024 meningkat menjadi $70 \%$ dan meningkat $10 \%$ untuk tiap 5 tahun berikutnya sampai akhir periode perencanaan. Dengan demikian tingkat pelayanan tahun 2029dan 2034 diskenariokan $80 \%$ dan $90 \%$ (sesuai standar perencanaan).

- Kebutuhan Domestik, Kebutuhan domestik akan dilayani dengan Sambungan Rumah (SR) dan Kran Umum $\mathrm{KU})$ dengan perbandingan pelayanan SR : KU adalah $70: 30$ sampai tahun 2018 dan layanan SR : KU sebesar 80 : 20 mulai tahun 2023 sampai akhir tahun perencanaan.

- Kebutuhan Non Domestik: 30\% dari kebutuhan Domestik.

- Kehilangan Air, Kehilangan air ditetapkan $30 \%$ dari kebutuhan total dan menurun sampai $20 \%$ di akhir periode perencanaan.

- Kapasitas produksi, derencanakan $10 \%$ kebutuhan harian rata-rata.

Selengkapnya kriteria perhitungan kebutuhan air bersih di Kawasan Pusat Pertumbuhan Rancabuayaakan dijelaskan dalam tabel berikut.

Tabel 9

Kriteria Perhitungan Kebutuhan Air Bersih di Wilayah Pusat Pertumbuhan Rancabuaya

\begin{tabular}{|clccccc|}
\hline N & Kompone & \multicolumn{6}{c|}{ Tahun Perencanaan } \\
\hline $\mathbf{1}$ & \multicolumn{1}{c|}{$\begin{array}{l}\text { Tingkat } \\
\text { pelayana } \\
\text { n (\%) }\end{array}$} & $\mathbf{2 0 1 4}$ & $\mathbf{2 0 1 9}$ & $\mathbf{2 0 2 4}$ & $\mathbf{2 0 2 9}$ & $\mathbf{2 0 3 4}$ \\
\hline $\mathbf{2}$ & $\begin{array}{l}\text { Pelayana } \\
\text { n SR : } \\
\text { KU }\end{array}$ & $70: 30$ & $70: 30$ & 80 & 80 & 90 \\
\hline $\mathbf{3}$ & \multicolumn{7}{c}{} & & \\
\hline & SR & 130 & 130 & 130 & 150 & 150 \\
\hline & KU & 30 & 30 & 30 & 30 & 30 \\
\hline
\end{tabular}

\begin{tabular}{|clccccc|}
\hline $\mathbf{4}$ & $\begin{array}{l}\text { Konsums } \\
\text { i Non } \\
\text { Domestik }\end{array}$ & $\begin{array}{c}30 \% \\
\text { domesti } \\
\mathrm{k}\end{array}$ & $\begin{array}{c}30 \% \\
\text { domesti } \\
\mathrm{k}\end{array}$ & $\begin{array}{c}30 \% \\
\text { domesti } \\
\mathrm{k}\end{array}$ & $\begin{array}{c}30 \% \\
\text { domesti } \\
\mathrm{k}\end{array}$ & $\begin{array}{c}30 \% \\
\text { domesti } \\
\mathrm{k}\end{array}$ \\
\hline $\mathbf{5}$ & $\begin{array}{l}\text { Kehilang } \\
\text { an Air }\end{array}$ & $30 \%$ & $30 \%$ & $25 \%$ & $25 \%$ & $20 \%$ \\
\hline $\mathbf{6}$ & $\begin{array}{l}\text { Faktor } \\
\text { Hari } \\
\text { Maksimu } \\
\mathrm{m}\end{array}$ & 1,1 & 1,1 & 1,1 & 1,1 & 1,1 \\
\hline
\end{tabular}

Berdasarkan asumsi yang telah ditetapkan di atas, maka perkiraan total kebutuhan air bersih sampai tahun 2034 di Kawasan Pusat Pertumbuhan Rancabuaya dapat dilihat pada tabel dibawah ini.

Tabel 10

Proyeksi Kebutuhan Air Bersih di Kawasan Pusat Pertumbuhan Rancabuaya

Tahun 2014-2034

\begin{tabular}{|ccccc|}
$\begin{array}{c}\text { Tahu } \\
\mathbf{n}\end{array}$ & $\begin{array}{c}\text { Jumlah } \\
\text { Pendudu } \\
\mathbf{k}\end{array}$ & $\begin{array}{c}\text { Pendudu } \\
\mathbf{k} \\
\text { Terlayan } \\
\mathbf{i}\end{array}$ & \multicolumn{2}{c|}{$\begin{array}{c}\text { Domestik } \\
\text { (Lt/org/Hari) }\end{array}$} \\
\hline $\mathbf{2 0 1 4}$ & 227,415 & 81,869 & $7,450,115$ & \multicolumn{1}{c|}{$\mathbf{K U}$} \\
\hline $\mathbf{2 0 1 9}$ & 235,818 & 117,909 & $10,729,71$ & $1,061,18$ \\
& & & 9 & 1 \\
\hline $\mathbf{2 0 2 4}$ & 244,716 & 171,301 & $15,588,40$ & $1,541,71$ \\
& & & 9 & 1 \\
\hline $\mathbf{2 0 2 9}$ & 254,137 & 203,310 & $18,501,17$ & $1,829,78$ \\
& & & 4 & 6 \\
\hline $\mathbf{2 0 3 4}$ & 264,113 & 237,702 & $21,630,85$ & $2,139,31$ \\
& & & 5 & 5 \\
\hline
\end{tabular}

\begin{tabular}{|lclll|}
\multicolumn{1}{c}{$\begin{array}{c}\text { Total } \\
\text { Domestik }\end{array}$} & $\begin{array}{c}\text { Non } \\
\text { Domestik }\end{array}$ & $\begin{array}{c}\text { Kehilangan } \\
\text { air }\end{array}$ & \multicolumn{2}{c|}{ Total Kebutuhan } \\
(Lt/Hari) & (Lt/Detik) \\
\hline $\mathbf{8 , 1 8 6 , 9 4 0}$ & $2,456,082$ & $3,192,907$ & $13,835,929$ & 160.14 \\
\hline $\mathbf{1 1 , 7 9 0 , 9 0 0}$ & $3,537,270$ & $4,598,451$ & $19,926,621$ & 230.63 \\
\hline $\mathbf{1 7 , 1 3 0 , 1 2 0}$ & $5,139,036$ & $5,567,289$ & $27,836,445$ & 322.18 \\
\hline $\mathbf{2 0 , 3 3 0 , 9 6 0}$ & $6,099,288$ & $6,607,562$ & $33,037,810$ & 382.38 \\
\hline $\mathbf{2 3 , 7 7 0 , 1 7 0}$ & $7,131,051$ & $6,180,244$ & $37,081,465$ & 429.18 \\
\hline
\end{tabular}

\section{Air Limbah/Kotor}

Air limbah secara umum terbagi kedalam dua kelompok, yaitu limbah domestik dan limbah industri. Air limbah domestik atau dari kegiatan rumah tangga ini ada dua macam, pertama adalah air limbah bekas mandi dan cuci, kedua adalah limbah kakus atau human waste.Air limbah yang dominan dewasa ini adalah air limbah domestik, yang terdiri atas air limbah bekas cuci dan mandi, serta air limbah faecal atau tinja. Pembuangan air limbah di Kawasan Pusat Pertumbuhan 
Rancabuayadilakukan secara individual pada masing-masing rumah tangga, sistem yang digunakan adalah sanitasi setempat (onsite sanitation). Sarana pengolahan air limbah WC dan toilet (black water) berupa tangki septik atau cubluk, sedangkan untuk air limbah bekas cuci dan air limbah dapur belum dilakukan pengolahan dan langsung dibuang ke saluran drainase dan sungai terdekat.

Pengembangan sistem pengelolaan air limbah erat hubungannya dengan upaya menciptakan sanitasi atau kesehatan lingkungan yang baik, sehingga pengelolaan air limbah ini harus benar-benar direncanakan dengan sebaik mungkin untuk menghindari hal-hal yang tidak diinginkan yang berhubungan dengan sanitasi lingkungan masyarakatnya.Pengelolaan air limbah rumah tangga dapat dilakukan secara:

- Setempar (onsite sanitation), adalah pengelolaan air limbah yang dilakukan di rumah masing-masing atau secara berkelompok membuang limbahnya pada suatu tempat;

- Terpusat (offsite sanitation), yaitu limbah dari masing-masing rumah tangga dibuatkan saluran dan dialirkan secara bersamaan ke suatu tempat untuk diolah.

Secara umum kondisi pelayanan prasarana air limbah secara teknis belum memadai. Untuk meningkatkan kondisi dan tingkat pelayanan air limbah, maka yang dibutuhkan adalah:

- Pembangunan sarana sanitasi setempat, baik secara individual maupun komunal.

- Penyuluhan personil instansi pengolahan dan penyuluhan kepada penduduk dalam peningkatan aspirasi masyarakat untuk membangun sendiri sarana sanitasi di tempat tinggalnya masing-masing dan meningkatkan pengetahuan masyarakat mengenai pengelolaan air limbah.

Monitoring untuk memantau pengelolaan air limbah domestik maupun non domestik, serta kualitas dan kuantitas badan-badan air yang ada diperkotaan.

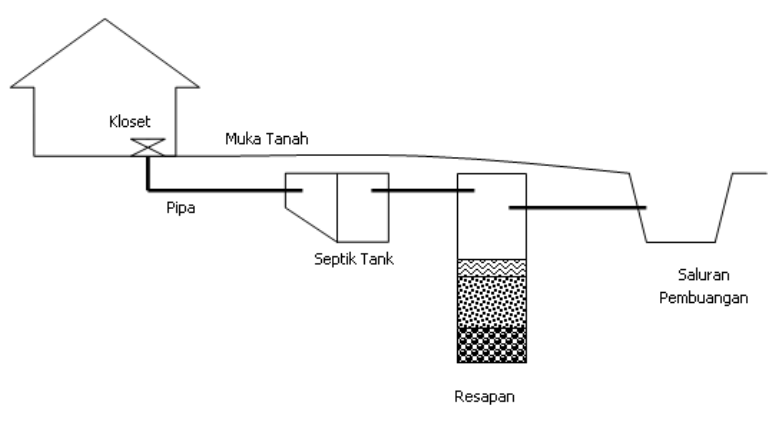

Gambar 9

Skema Penerapan Teknologi Pembuangan Air Limbah Sistem Setempat

Timbulan air limbah sangat dipengaruhi oleh pola pemakaian air bersih, pada umumnya timbulan air limbah yang dihasilkan kurang lebih $70 \%-80 \%$ dari pemakaian air bersih. Berdasarkan hasil perhitungan untuk perkiraan jumlah timbulan air limbah di Kawasan Pusat Pertumbuhan Rancabuaya pada tahun 2014 sebesar $9.685 \mathrm{~m} 3 /$ hari dari total kebutuhan air bersih, sedangkan pada akhir tahun perencanaan (2034) timbulan air limbah sebesar $25.957 \mathrm{~m} 3 /$ hari. Untuk lebih jelasnya dapat dilihat pada tabel dibawah ini.

Tabel 11

Proyeksi Timbulan Air Limbah di Kawasan Pusat Pertumbuhan

RancabuayaTahun 2013-2033

\begin{tabular}{|c|c|c|c|c|c|c|}
\hline \multirow[t]{2}{*}{$\begin{array}{l}\text { Tah } \\
\text { un }\end{array}$} & \multirow{2}{*}{$\begin{array}{c}\text { Jumla } \\
\text { h } \\
\text { Pendu } \\
\text { duk }\end{array}$} & \multirow{2}{*}{$\begin{array}{c}\begin{array}{c}\text { Pendu } \\
\text { duk }\end{array} \\
\text { Terla } \\
\text { yani }\end{array}$} & \multicolumn{2}{|c|}{$\begin{array}{c}\text { Kebutuhan Air } \\
\text { Bersih }\end{array}$} & \multicolumn{2}{|c|}{$\begin{array}{l}\text { Timbunan Air } \\
\text { Limbah }\end{array}$} \\
\hline & & & $\begin{array}{l}(\mathbf{L t} / \mathbf{H} \\
\text { ari) }\end{array}$ & $\begin{array}{l}\text { (M3/h } \\
\text { ari) }\end{array}$ & $\begin{array}{l}(\mathbf{L t} / \mathbf{H} \\
\text { ari) }\end{array}$ & $\begin{array}{l}\text { (M3/h } \\
\text { ari) }\end{array}$ \\
\hline 201 & 227,41 & 81,86 & 13,835 & & 9,685 , & 9,685 \\
\hline 4 & 5 & 9 & ,929 & 13,836 & 150 & \\
\hline 201 & 235,81 & 117,9 & 19,926 & & 13,948 & 13,94 \\
\hline 9 & 8 & 09 &, 621 & 19,927 & ,635 & 9 \\
\hline 202 & 244,71 & 171,3 & 27,836 & & 19,485 & 19,48 \\
\hline 4 & 6 & 01 & ,445 & 27,836 &, 512 & 6 \\
\hline 202 & 254,13 & 203,3 & 33,037 & & 23,126 & 23,12 \\
\hline 9 & 7 & 10 &, 810 & 33,038 & ,467 & 6 \\
\hline 203 & 264,11 & 237,7 & 37,081 & & 25,957 & 25,95 \\
\hline 4 & 3 & 02 & ,465 & 37,081 & ,026 & 7 \\
\hline
\end{tabular}

Melihat kebutuhan pengelolaan air limbah, serta besarnya investasi yang digunakan untuk pembuatan saluran air limbah, maka untuk Kawasan Pusat Pertumbuhan Rancabuaya pengelolaan air limbahnya dilakukan secara individu oleh masyarakat dengan menggunakan sistem setempat (onsite sanitation) dan secara komunal pada kawasan perumahan, perdagangan dan lain-lain. 


\section{Energi Listrik}

Listrik merupakan suatu bentuk energi yang disalurkan melalui saluran kabel mulai dari pusat pembangkit sampai ke pusat beban. Sedangkan jaringan listrik merupakan satu kesatuan sistem jaringan yang terdiri dari sumber pembangkit listrik, gardu induk/gardu hubung, gardudistribusi, jaringan kabel tegangan tinggi, tegangan menengah dan tegangan rendah. Komponen utama dalam jaringan listrik, yaitu:

- Sistem pembangkit, terdiri dari sejumlah unit-unit pembangkit yang umumnya tersebar luas pada daerah pelayanan.

- Sistem transmisi, merupakan sistem penyaluran tenaga listrik bertegangan tinggi ke pusat-pusat beban dalam jumlah besar.

- Sistem distribusi, merupakan sistem saluran yang berfungsi membagikan tenaga listrik ke pihak pemakai melalui saluran tegangan rendah.

Energi listrik merupakan salah satu kebutuhan utilitas yang sangat diperlukan dalam menunjang aktivitas kawasan. Di masa datang, kebutuhan listrik akan semakin meningkat seiring dengan pertambahan jumlah penduduk dan perkembangan kota yang terjadi. Adapun hal-hal yang perlu dipertimbangkan dalam merencanakan perletakan jaringan listrik di wilayah perencanaan adalah dalam menetapkan lokasi gardu listrik yang diperlukan dan sistem jaringan distribusi. Untuk pemilihan lokasi gardu hubung harus melingkupi seluruh titik beban. Hal ini untuk meminimasi biaya momen beban yang merupakan perkalian besarnya beban dengan jarak ke titik suplly. Untuk kedepannya pembangunan jaringan listrik menggunakan jaringan yang berjenjang yaitu berurutan mulai dari jaringan primer, sekunder dan tersier. Pelayanan listrik di Kawasan Pusat Pertumbuhan Rancabuaya dilayani oleh PLN Cabang Pameungpeuk Kabupaten Garut.

Untuk memperkirakan kebutuhan listrik di Kawasan Pusat Pertumbuhan Rancabuayapada akhir tahun perencanaan dihitung berdasarkan standar dan asumsi kebutuhan listrik di daerah perkotaan. Perkiraan kebutuhan energi listrik direncanakan dengan menggunakan beberapa kriteria sebagai berikut :

- Jumlah Rumah Tangga dengan asumsi 1 Rumah Tangga/KK terdapat 5 orang

- Standar kebutuhan 1 rumah tangga 900 Watt

- Fasilitas Umum 30\% dari kebutuhan rumah tangga

- Penerangan Jalan 2\% dari kebutuhan rumah tangga

Berdasarkan asumsi tersebut maka kebutuhan listrik di Kawasan Pusat Pertumbuhan Rancabuayahingga tahun 2034 dapat dijelaskan pada tabel berikut.

Tabel 12

Proyeksi Timbulan Air Limbah di Kawasan Pusat Pertumbuhan

Rancabuaya Tahun 2013-2033

\begin{tabular}{|c|c|c|c|c|c|}
\hline \multirow{2}{*}{$\begin{array}{c}\text { Tah } \\
\text { un }\end{array}$} & \multirow{2}{*}{$\begin{array}{l}\text { Jumlah } \\
\text { Pendud } \\
\text { uk }\end{array}$} & \multicolumn{4}{|c|}{ Kebutuhan Listrik } \\
\hline & & $\begin{array}{c}\text { Kapasit } \\
\text { as } \\
\text { Listrik } \\
\text { RT }\end{array}$ & $\begin{array}{l}\text { Fasilitas } \\
\text { Umum } \\
\text { (Watt) }\end{array}$ & $\begin{array}{c}\text { Penerang } \\
\text { an } \\
\text { Jalan } \\
\text { (Watt) }\end{array}$ & $\begin{array}{c}\text { Total } \\
\text { (Watt) }\end{array}$ \\
\hline 2014 & $\begin{array}{r}227,4 \\
15\end{array}$ & $\begin{array}{r}40,934,70 \\
0\end{array}$ & $12,280,410$ & 818,694 & $\begin{array}{r}54,033,80 \\
4\end{array}$ \\
\hline 2019 & 235,8 & $42,447,24$ & & 848,945 & $56,030,35$ \\
\hline & 18 & 0 & $12,734,172$ & & 7 \\
\hline 2024 & $\begin{array}{r}244,7 \\
16\end{array}$ & $\begin{array}{r}44,048,88 \\
0\end{array}$ & $13,214,664$ & 880,978 & $\begin{array}{r}58,144,52 \\
2\end{array}$ \\
\hline 2029 & $\begin{array}{r}254,1 \\
37\end{array}$ & $\begin{array}{r}45,744,66 \\
0\end{array}$ & $13,723,398$ & 914,893 & $\begin{array}{r}60,382,95 \\
1\end{array}$ \\
\hline 2034 & $\begin{array}{r}264,1 \\
13\end{array}$ & $\begin{array}{r}47,540,34 \\
0\end{array}$ & $14,262,102$ & 950,807 & $\begin{array}{r}62,753,24 \\
9\end{array}$ \\
\hline
\end{tabular}

Sumber : Hasil Analisis, Tahun 2017

Berdasarkan perhitungan tersebut maka kebutuhan daya listrik untuk mendukung pengembangan Kawasan Pusat Pertumbuhan Rancabuaya dapat diperkirakan untuk tahun 2014 sebesar 54,033,804 watt, sedangkan untuk akhir tahun perencanaan (2034) kebutuhan daya listriknya diperkirakan sebesar 62,753,249 watt.

Perhitungan tersebut merupakan kebutuhan minimum yang harus dipenuhi oleh pemerintah. Pengembangan jaringan listrik di Kawasan Pusat Pertumbuhan Rancabuaya sebaiknya dilakukan secara bertahap, sesuai dengan perkembangan penduduk dan kegiatan yang berlangsung pada tahun-tahun perencanaan, ini disebabkan karena tingkat kebutuhan energi listrik dipengaruhi oleh proyeksi jumlah penduduk pada tahun perencanaan. Kebutuhan energi listrik (rumah tangga, non rumah tangga dan penerangan jalan) pada tiap-tap desa berbeda-beda. 
Pengembangan ini sebaiknya terpadu dengan pengembangan jaringan lainnya seperti air bersih, telepon dan mengikuti jaringan jalan, selain tidak menimbulkan kesulitan dalam pengaturan jaringan listrik juga untuk menghindarkan pekerjaan yang tumpang tindih pada suatu lokasi yang sama, selain itu dimaksudkan untuk mengarahkan perkembangan kot

\section{Telekomunikasi}

Telepon adalah suatu alat telekomunikasi yang berfungsi untuk mengirim dan menerima informasi berupa tanda, gambar, suara yang dipindahkan melalui system kawat, optic, radio atau sistem elektromagnetik lainnya. Penyediaan jaringan telepon menjadi sangat penting dengan berbagai perkembangan yang ada di Kawasan Pusat Pertumbuhan Rancabuaya, seperti kegiatan perumahan, perdagangan dan fasilitas umum yang tentunya membutuhkan komunikasi yang terus meningkat.

Standar perencanaan telepon untuk rumah tangga di standarkan yaitu 1 unit SST, melayani 100 jiwa, sambungan telepon umum melayani 2.500 jiwa. Untuk lebih jelasnya analisis untuk kebutuhan telekomunikasi dari tahun 2014 sampai dengan 2034 dapat dilihat dari tabel berikut.

\section{Tabel 13}

Proyeksi Kebutuhan Telekomunikasi di Kawasan Pusat Pertumbuhan

Rancabuaya Tahun 2013-2033

\begin{tabular}{|c|c|c|c|c|}
\hline \multirow{2}{*}{$\begin{array}{l}\text { Tah } \\
\text { un }\end{array}$} & \multirow{2}{*}{$\begin{array}{l}\text { Jumlah } \\
\text { Penduduk }\end{array}$} & \multicolumn{3}{|c|}{ Perkiraan Sambungan Telepon } \\
\hline & & $\begin{array}{c}\text { Telepon } \\
\text { Rumah Tangga } \\
\text { (SST) }\end{array}$ & $\begin{array}{c}\text { Telepon } \\
\text { Fasos } \\
\text { Fasum }\end{array}$ & $\begin{array}{l}\text { Telepon } \\
\text { Umum } \\
\text { (SST) }\end{array}$ \\
\hline 2014 & 227,415 & 11,371 & 355 & 91 \\
\hline 2019 & 235,818 & 11,791 & 368 & 94 \\
\hline 2024 & 244,716 & 12,236 & 382 & 98 \\
\hline 2029 & 254,137 & 12,707 & 397 & 102 \\
\hline 2034 & 264,113 & 13,206 & 413 & 106 \\
\hline
\end{tabular}

\section{Drainase}

Jaringan drainase di Kawasan Pusat Pertumbuhan Rancabuaya ditinjau dari segi pelayanannya terdiri atas system drainase utama (mayor) terdiri atas sungai-sungai besar yaitu : Cigadog, Sungai cihideung, Sungai cipancong, sungai Cisadea-Cibareno, Gunung Herang, Gn Pasir Angin. Jenis Saluran darinase pada jaringan jalan utama menggunakan saluran terbuka untuk mengalirkan air hujan dari pasangan bata.Sedangkan jaringan drainase mikro (local) yaitu saluran drainase kota yang berada pada jaringan jalan utama dan lingkungan.

Pengembangan jaringan drainase harus dilakukan secara menyeluruh yaitu harus melihat keterkaitan antara jaringan, juga antar guna lahan, sehingga tercipta sistem drainase kota terpadu. Selain itu juga disesuaikan dengan pengembangan jaringan jalan yang ada. Pengembangan guna lahan perumahan maupun guna lahan terbangun lainnya harus pula memperhatikan kesesuaian jaringan drainase yang ada hingga tidak terjadi terputusnya saluran drainase.

Tujuan utama dibangunnya saluran drainase di Kawasan Pusat Pertumbuhan Rancabuaya adalah untuk:

1. Mengalirkan limpasan air hujan agar tidak terjadi genangan air/ banjir, yaitu dengan membuat jaringan drainase dengan kapasitas dan desain geometrik yang memadai atau sesuai dengan kondisi alamnya.

2. Menampung limpasan air hujan dalam bentuk catchment area atau waduk dari sistem saluran pembuangan air hujan untuk dijadikan sebagai sumber air baku secara komunal.

3. Menampung air hujan dalam suatu tempat melalui upaya pembuatan sumur-sumur penampung air hujan di setiap rumah untuk dijadikan sebagai sumber air baku secara individu.

4. Mengantisipasi agar tidak terjadi banjir di masa mendatang melalui pengembangan sistem jaringan drainase yang berhirarki, terpadu dan saling terintegrasi antar kawasan dan dengan sistem jaringan drainase kotanya.

Sejalan dengan perkembangan kota, maka perlu pula diperhatikan perkembangan saluran drainase jalan yang ada di Kawasan Pusat Pertumbuhan Rancabuaya. Upaya-upaya yang perlu dilakukan adalah:

\# Memperbaiki dan meningkatkan saluran drainase jalan yang telah ada. Diterapkan pada beberapa ruas jalan yang mempunyai saluran drainase yang belum dilakukan perkerasan dengan batu kali, tetapi masih berupa saluran dari tanah. Juga ada 
beberapa saluran yang ditumbuhi alangalang sehingga alirannya tidak lancar;

\# Membuat saluran drainase baru pada jalan yang belum ada salurannya. Dengan pembangunan saluran drainase baru ini diharapkan aliran drainase yang ada di Kawasan Pusat Pertumbuhan Rancabuaya menjadi tidak terputus satu sama lain, dimana sebelum ada saluran drainase alirannya banyak terputus.
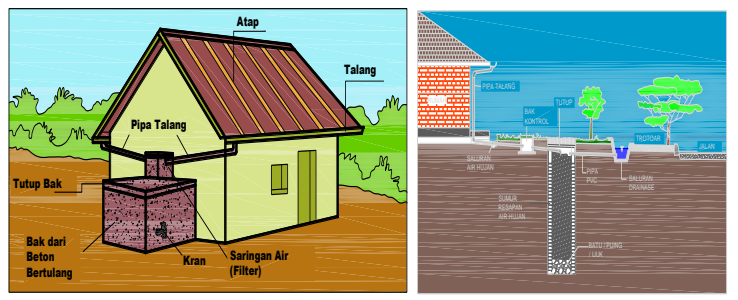

Gambar 10 Contoh Fasilitas Pemanenan Air Hujan di Kawasan Permukiman Pada Kawasan

\section{Persampahan}

Sampah adalah suatu bahan buangan yang tidak cair atau disebut juga limbah padat. Limbah padat atau $1 / 2$ padat berasal dari berbagai aktivitas lingkungan masyarakat, baik dari masyarakat permukiman, perdagangan, industri maupun dari masyarakat pertanian, dsb. Sampah terdiri dari bahan organik dan anorganik, logam dan atau logam, dapat terbakar dan atau tidak terbakar.Sampah bersumber dari daerah permukiman, daerah perkantoran, daerah komersil, daerah pariwisata, daerah pelayanan masyarakat (sekolah, rumah sakit, tempat ibadah), tempat fasilitas umum (jalan, pertamanan, riool dan WC umum). Bahan asal sampah berasal dari tumbuh-tumbuhan, daging hewan dan ikan, kotoran manusia dan hewan, bahan logam, bahan non logam, dll.

Masalah persampahan di Kawasan Pusat Pertumbuhan Rancabuaya sampai saat ini belum menimbulkan persoalan karena penduduk pada umumnya membuang sampah ke tanah kosong dan membakar sampah di pekarangan rumahnya, tetapi meskipun demikian tetap diperlukan suatu usaha untuk tetap menjaga kebersihan dan keasrian kota, dengan menerapkan sistem pengelolaan sampah secara terpadu mulai dari pengumpulan, pengangkutan dan pembuangan untuk menghindari timbulnya masalah perkotaan yang lebih kompleks karena polusi dan gangguan kesehatan masyarakat.

Sistem yang terkait dengan sistem pengelolaan sampah meliputi :

1. Pewadahan (on storage)

2. Pengumpulan (collection)

3. Pemindahan (transfer)

4. Pengangkutan (transportation)

5. Pembuangan Akhir (disposal)

Beberapa kriteria penting yang akan dipertimbangkan untuk memperkirakan volume sampah di Kawasan Pusat Pertumbuhan Rancabuayaadalah sebagai berikut :

- Jumlah Rumah Tangga dengan asumsi 1 Rumah Tangga/KK terdapat 5 orang

- Produksi sampah domestik 2,2 1t/org/hari

- Produksi sampah non domestik $20 \%$ dari sampah domestik

Standar kebutuhan prasarana persampahan yang digunakan, yaitu :

- Gerobak Sampah : $2 \mathrm{~m}^{3}$

- Kontainer : $6 \mathrm{~m}^{3}$

- Transfer depo : $200 \mathrm{~m}^{3}$

- Arm Roll Truck : $6 \mathrm{~m}^{3}$

Perkiraan timbulan sampah domestik yang dihasilkan oleh penduduk Kawasan Pusat Pertumbuhan Rancabuaya tahun 2014 yaitu sebesar 500.313 ltr/org/hari sedangkan pada akhir tahun perencanaan (2034) sebesar 581.048,60 ltr/org/hari. Untuk lebih jelasnya mengenai perkiraan timbulan sampah dan kebutuhan prasarana persampahan di Kawasan Pusat Pertumbuhan Rancabuaya dapat dilihat pada tabel dibawah ini 
Tabel 14

Proyeksi Timbulan Sampah Kawasan Pusat Pertumbuhan Rancabuaya Tahun 2013-2033

\begin{tabular}{|ccccccc|}
\hline $\begin{array}{c}\text { Ta } \\
\text { hu } \\
\mathrm{n}\end{array}$ & $\begin{array}{c}\text { Juml } \\
\text { ah } \\
\text { Pend } \\
\text { uduk }\end{array}$ & $\begin{array}{c}\text { Jumlah } \\
\text { KK } \\
(1 \mathrm{KK}= \\
5 \text { orng) }\end{array}$ & $\begin{array}{c}\text { timbulan } \\
\text { sampah } \\
(2,2 \\
\text { ltr/orng/h } \\
\text { r) }\end{array}$ & $\begin{array}{c}\text { Timbulan } \\
\text { Sampah } \\
\text { Non- } \\
\text { Domestik } \\
\text { (20\% dari } \\
\text { domestik) }\end{array}$ & $\begin{array}{c}\text { Total } \\
\text { Timbulan } \\
\text { Sampah } \\
\text { (lt/org/hr) }\end{array}$ & $\begin{array}{c}\text { Total } \\
\text { Timbula } \\
\text { n } \\
\text { Sampah } \\
(\mathrm{m} 3 / \mathrm{hr})\end{array}$ \\
\hline $\mathbf{2 0}$ & 227,4 & 45,483 & $500,313$. & $100,062.60$ & $600,375.6$ & 600.38 \\
$\mathbf{1 4}$ & 15 & & 00 & & 0 & \\
\hline $\mathbf{2 0}$ & 235,8 & 47,164 & $518,799$. & $103,759.92$ & $622,559.5$ & 622.56 \\
$\mathbf{1 9}$ & 18 & & 60 & & 2 & \\
\hline $\mathbf{2 0}$ & 244,7 & 48,943 & $538,375$. & $107,675.04$ & $646,050.2$ & 646.05 \\
$\mathbf{2 4}$ & 16 & & 20 & & 4 & \\
\hline $\mathbf{2 0}$ & 254,1 & 50,827 & $559,101$. & $111,820.28$ & $670,921.6$ & 670.92 \\
$\mathbf{2 9}$ & 37 & & 40 & & 8 & \\
\hline $\mathbf{2 0}$ & 264,1 & 52,823 & $581,048$. & $116,209.72$ & $697,258.3$ & 697.26 \\
$\mathbf{3 4}$ & 13 & & 60 & & 2 & \\
\hline
\end{tabular}

Sumber : Hasil Analisis,

Tabel 15

Proyeksi Kebutuhan Prasarana Sampah Kawasan Pusat Pertumbuhan Rancabuaya Tahun 2013-2033

\begin{tabular}{|rrrr|}
\hline Tahun & $\begin{array}{c}\text { Jumlah } \\
\text { Penduduk }\end{array}$ & $\begin{array}{c}\text { Gerobak } \\
\text { Sampah }\end{array}$ & Kontainer \\
\hline $\mathbf{2 0 1 4}$ & 227,415 & 300 & 100 \\
\hline $\mathbf{2 0 1 9}$ & 235,818 & 311 & 104 \\
\hline $\mathbf{2 0 2 4}$ & 244,716 & 323 & 108 \\
\hline $\mathbf{2 0 2 9}$ & 254,137 & 335 & 112 \\
\hline $\mathbf{2 0 3 4}$ & 264,113 & 349 & 116 \\
\hline
\end{tabular}

Sumber : Hasil Analisis, Tahun 2017

Menurut standar sistem pembuangan sampah terpadu, sampah-sampah rumah tangga disimpan di dalam bak sampah yang terdapat pada masing-masing rumah, kemudian dikumpulkan dengan menggunakan gerobak sampah ke Tempat Pembuangan Sementara (TPS) yang kemudian diangkut untuk diteruskan ke Tempat Pembuangan Akhir (TPA). Masing-masing TPS melayani 1.000 penduduk, sedangkan TPA melayani satu kota tergantung kapasitas TPA yang disediakan.

Untuk wilayah yang dipengaruhi oleh kegiatan perkotaan, pengolahan sampah yang dapat dilakukan adalah dengan mengacu pada pengolahan sampah kota. Dimana pengolahan sampah kota yang sedang digalakkan oleh pemerintah adalah dengan menerapkan sistem pengolahan sampah terpadu Program 4R : pemanfaatan kembali, (Reuse), Pengurangan (Reduce), daur ulang (Recycle) dan pengurangan jumlah sampah yang satu menjadi sampah lain yang jumlahnya lebih sedikit/ kecil (Replace). Sedangkan pengolahan sampah untuk wilayah yang dipengaruhi oleh kegiatan pedesaan, dapat dilakukan dengan cara pengolahan sampah mandiri dan produktif berbasis masyarakat.

\section{Analisis Sistem Transportasi}

\section{Jalan}

Dalam mewujudkan prasarana transportasi darat yang melalui jalan, harus terbentuk wujud jalan yang menyebabkan pelaku perjalanan baik orang maupun barang, selamat sampai di tujuan, dan dalam mendukung kegiatan ekonomi, sosial, budaya dan lingkungan. Perjalanan harus dapat dilakukan secepat mungkin dengan biaya perjalanan yang adil sehingga dapat dijangkau oleh semua lapisan masyarakat. Jaringan jalan yang perlu dikembangkan di Kawasan Rancabuaya diantaranya :

- Ruas jalan Lintas Selatan Jawa Barat;

Traisfe Ruas jalanoll Rancabuaya-Talegong-CisewuDepo Pangalengan; ntainer

- Jalan alternative Caringin - Cisewu;

- Rguas jalan Caringipos Indralayang; dan

- Rzuas jalan yange8 berada di Kawasan Rancabuaya. 112

\subsection{Angkutan Umuhh6}

Moda angkutan yang tersedia di Kawasan Rancabuaya dalam menunjang pergerakan barang dan orang terdiri dari moda angkutan antara kota dan dan antar pedesaan. Jenis angkutan yang melayani pola pergerakan penduduk yaitu:

- Angkutan Kota yang melayani pola pergerakan penduduk yang akanmenuju dan keluar wilayah perencanaan, rute angkutan umum yang ada menghubungkan wilayah perencanaan dengan wilayah-wilayah sekitarnya.

- Angkutan Bak Terbuka, adalah jenis angkutan yang melayani pergerakan antar desa dan antar kecamatan, adapun angkutan pedesesaan ini melayani pergerakan ke Kecamatan dan antar desa di Kawasan Rancabuaya.

- Ojeg, yang melayani daerah-daerah yang belum terlayani angkutan umum, terutama pada desa/kawasan-kawasan perumahan yang tidak terlintasi oleh rute angkutan umum.

\section{Terminal}

Fungsi utama terminal adalah penyediaan sarana masuk dan ke luar bagi obyek-obyek (penumpang atau barang) yang akandigerakkan menuju atau dari subsistem jaringan transportasi. Beberapa jenis terminal hanya memiliki satu fungsi yaitu bongkar dan 
muat, jenis lainnya dapat menyelenggarakan beberapa fungsi sekaligus, selain bongkar dan muat juga menyediakan fasilitas menunggu yang nyaman bagi calon penumpang, menyediakan fasilitas untuk menyimpan muatan dan melindunginya dari kemungkinan rusak atau hilang, seringkali juga merupakan tempat di mana kendaraan-kendaraan transportasi diparkir dan dipelihara. Pengembangannya terminal di Kawasan Rancabuaya yaitu Terminal tipe B yang di arahkan di Dusun Mekarsari dengan luas $\pm 1,523$ Ha yang berdekatan dengan kawasan pariwisata Pantai Rancabuaya sebagai akses utama adalah Jalan Nasional Jabar Selatan.

\section{Pelabuhan}

Pembangunan sektor perikanan dan kelautan merupakan bagian dari pembangunan ekonomi yang bertujuan untuk meningkatkan taraf hidup masyarakat pada umumnya serta para nelayan dan petani ikan pada khususnya. Untuk memacu perkembangan dan pertumbuhan usaha perikanan serta peningkatan taraf hidup nelayan, Pemerintah menyediakan berbagai fasilitas yang dibutuhkan nelayan, yaitu Tempat Pelelangan Ikan (TPI), Pangkalan Pendaratan Ikan (PPI) danPelabuhan Perikanan Pantai (PPP).

Pada saat ini di Kawasan Rancabuaya telah memiliki 1 unit Tempat Pelelangan Ikan (TPI) Pelabuhan Ciliab yang memiliki kelengkapan perahu dan alat tangkap yang ke depannya perlu dikembangkan atau ditata ulang. Selain TPI, di Kawasan Racabuaya perlu dibangun PPI Rancabuaya, dimana kedepannya mempunyai peran dan fungsi sebagai pusat perikanan laut di Kecamatan Caringin khususnya dan di Garut Selatan pada umumnya dalam upaya peningkatan pendapatan nelayan. Kegiatan PPI Rancabuaya akan diarahkan pada usaha meningkatkan kontribusi sektor perikanan dalam upaya menunjang peran serta laju pertumbuhan sektor perikanan dalam pembangunan nasional.

Selain itu disekitar kawasan Rancabuaya terdapat juga PPP Cilauteureun serta PPI Jayanti yang sangat perlu untuk dikembangkan mengingat adanya potensi perikanan tangkap di sana yangbelum termanfaatkan. Fakta menunjukan bahwa produksi perikanantangkap Kabupaten Garut adalah yang terbesar kedua setelahProposal Pengembangan Pelabuhan Perikanan di Pansela Jabar Hlm. 20Kabupaten Sukabumi $(44,18 \%$ dari total produk perikanan tangkapPansela Jabar). Keberadaan kapal berukuran 5-10 GT yangberpangkalan disana memberi kontribusi pada hasiltangkapan ikan di Kabupaten Garut serta Kabupaten Cianjur.

Untuk lebih jelasnya mengenai sistem transportasi Kawasan Pusat Pertumbuhan Rancabuaya dapat dilihat pada Gambar 4.5 dibawah ini.

\section{Analisis Kawasan Kecamatan Caringin}

\section{Kedudukan Kecamatan Caringin dalam Rencana Struktur Ruang Provinsi Jawa Barat (RTRWP)}

Dalam RTRW Provinsi Jawa Barat ditetapkan bahwa Kecamatan Caringin khususnya Kawasan Pariwisata Rancabuaya (Desa Purbayani) merupakan Pusat Kegitan Wilayah Promosi (PKWp). Dalam penetapannya, tentunya terdapat kriteria yang perlu dipenuhi yaitu meliputi pengadaan fasilitas minimum yaitu :

a. Perhubungan : pelabuhan udara dan/atau pelabuhan dan/atau terminal tipe B

b. Ekonomi : pasar induk regional

c. Kesehatan : rumah sakit umum tipe B

d. Pendidikan : perguruan tinggi

Penetapan kawasan pariwisata Rancabuaya sebagai PKWp memberikan keuntungan bagi peningkatan daya tarik pariwisata Rancabuaya, serta mampu meningkatkan kegiatan perekonomian masyarakatnya. Akan tetapi, penetapan PKWp ini tidak didukung dengan tersedianya jaringan jalan yang baik. Masih terdapat jaringan jalan dengan kondisi buruk dari arah Kota GarutPameungpeuk-Rancabuaya. Hal ini perlu diperhatikan kembali karena dalam pengembangan PKWp Rancabuaya terdapat pusat kegiatan pendukung dalam lingkup Kabupaten Garut yaitu Pusat Kegiatan Lokal (PKL) Perkotaan Garut dan Pameungpeuk serta PKL Perdesaan Cikajang dan Bungbulang. 
2. Kedudukan Kecamatan Caringin dalam Rencana Struktur Ruang Kabupaten Garut (RTRW)

RTRW Kabupaten Garut menetapkan bahwa Kecamatan Caringin, Desa Purbayani (Rancabuaya) sebagai Pusat Kegiatan Wilayah (PKW) dengan fungsi kota, yaitu :

a. Pusat perdagangan, jasa dan pemasaran skala provinsi atau beberapa kabupaten/kota.

b. Pusat pelayanan sosial ekonomi skala provinsi beberapa kabupaten kota.

c. Pusat pelayanan transportasi skala provinsi/regional.

\section{Analisis Kedudukan Kecamatan Caringin} dalam Pola Ruang Regional

Kedudukan Kecamatan Caringin dalam Rencana Pola Ruang Kabupaten Garut (RTRW)

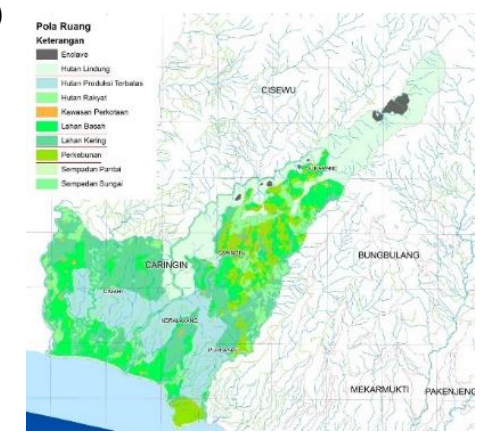

Gambar 11

Pola Ruang Kecamatan Caringin dalam RTRW Kabupaten Garut

Sumber : RTRW Kabupaten Garut

Berdasarkan rencana pola ruang Kabupaten Garut yang tertuang pada Gambar 2.4, Kecamatan Caringin memiliki pola ruang yang didominasi oleh kawasan hutan, pertanian dan perkebunan. Kawasan hutan yang mendominasi yakni kawasan hutan lindung yang persebarannya terdapat di Desa Sukarame. Sedangkan kawasan pertanian terdapat di Desa Caringin, Desa Cimahi, Desa Samudera Jaya, Desa Indralayang dan Desa Purbayani. Terakhir, Kawasan Perkebunan diarahkan di Desa Caringin dan Desa Sukarame.

\section{Analisis Kedudukan Kecamatan Caringin dalam Kawasan Strategis Regional Kedudukan Kecamatan Caringin dalam Rencana Kawasan Strategis Provinsi Jawa Barat (RTRWP)}

Kawasan Strategis Provinsi (KSP) yang sudah ditetapkan dalam RTRW Provinsi Jawa Barat adalah kawasan tertentu, salah satunya adalah KSP Garut Selatan.Kecamatan Caringin merupakan salah satu kecamatan yang termasuk kedalam lingkup KSP Garut Selatan. Kriteria dari KSP Garut Selatan yaitukawasan yang potensial menimbulkan masalah yang bersifat lintas kabupaten/kota, bersifat fisik lingkungan dan kebencanaan. Arahan penanganan KSP Garut Selatan adalah :

a. Mengembangkan Kota Garut Selatan secara terbatas sesuai daya dukung lingkungan.

b. Mengembangkan wisata IPTEK

\section{Kedudukan Kecamatan Caringin dalam Kawasan Strategis Kabupaten Garut (RTRW)}

Kawasan strategis Kabupaten (KSK) Kabupaten Garut berupa kawasan yang memiliki nilai strategis ekonomi yang berpengaruh terhadap pertumbuhan ekonomi, kawasan budidaya maupun lindung yang memiliki nilai strategis sosial budaya dan kawasan yang memiliki nilai strategis fungsi dan daya dukung lingkungan hidup. Kedudukan Kecamatan Caringin dalam Kawasan Strateis Kabupaten diantaranya sebagai berikut :

A. Kawasan Perbatasan Bagian Barat (CaringinCisewu-Talegong)

Kawasan yang dapat mempercepat pertumbuhan kawasan tertinggal di wilayah sekitarnya. Kawasan bagian barat yang berbatasan dengan Cianjur dan Kabupaten Bandung meliputi wilayah Kecamatan Caringin, Cisewu dan Talegong.Kawasan ini memiliki banyak limitasi untuk pengembangan wilayahnya. Topografi yang curam dengan kemiringan lereng rata-rata $25 \%$ hingga $40 \%$ menyebabkan kawasan ini memiliki fungsi sebagai kawasan lindung. Kondisi ini perlu strategi khusus dalam memacu pertumbuhan wilayahnya.

Isu Penanganan :

1. Sebagian besar memiliki fungsi sebagai kawasan lindung. Kondisi ini perlu strategi khusus dalam memacu pertumbuhan wilayahnya yang diharapkan dapat mempercepat pertumbuhan kawasan tertinggal di sekitarnya. 
2. Mengantisipasi terhadap potensi kerawanan terhadap konflik sosial.

B. Kawasan Koridor Jalan Lintas Jabar Selatan

Kawasan yang berpengaruh terhadap perkembangan wilayah koridornya termasuk Kawasan Garut bagian Selatan dengan dukungan jaringan prasarana dan fasilitas penunjang kegiatan ekonomi.Meliputi Kecamatan Cibalong, Pameungpeuk, Cikelet, Mekarmukti, Pakenjeng, Bungbulang dan Caringin.

Isu Penanganan :

1. Dukungan jaringan prasarana dan fasilitas penunjang kegiatan ekonomi.

2. Perlu sinergitas infrastruktur

3. Perlu sinergitas pembangunan antar wilayah.

a. Analisis Kependudukan

1. Laju pertumbuhan penduduk

Pertumbuhan penduduk dapat memberikan gambaran kepada suatu wilayah akan perkembangan wilayah tersebut. Sehingga perlu diketahui pula presentase laju pertumbuhan wilayah perencanaan selama 5 (lima) tahun yaitu sampai dengan tahun terakhir (2015). Dimana dari pertumbuhan tersebut maka dapat diproyeksikan jumlah pertambahan penduduk guna menganalisa jumlah fasilitas dan utilitas yang dibutuhkan sampai dengan akhir tahun perencanaan yaitu tahun 2035. Data pertumbuhan penduduk pada masing-masing Desa di Kecamatan Caringin pada tahun 2011-2015 dapat dilihat pada tabel 5.5 di bawah ini.

Tabel 16

Kepadatan Penduduk

\begin{tabular}{|c|c|c|c|c|c|c|c|c|c|c|c|}
\hline \multirow{2}{*}{$\mathrm{N}$} & \multirow{2}{*}{ Desa } & \multicolumn{5}{|c|}{ Jumlah Penduduk } & \multicolumn{5}{|c|}{ Laju Pertumbuhan Penduduk } \\
\hline & & 201 & 201 & 201 & 201 & 2015 & 2 & 20 & 20 & 20 & 20 \\
\hline 1 & Cimahi & $\begin{array}{r}3.0 \\
99\end{array}$ & $\begin{array}{r}3.3 \\
16\end{array}$ & $\begin{array}{l}3.3 \\
52\end{array}$ & $\begin{array}{l}3.3 \\
20\end{array}$ & 3.722 & 1 & $\begin{array}{c}0, \\
07\end{array}$ & $\begin{array}{c}0, \\
01\end{array}$ & $\overline{0}$ & $\begin{array}{l}0, \\
12\end{array}$ \\
\hline 2 & $\begin{array}{l}\text { Indralay } \\
\text { ang }\end{array}$ & $\begin{array}{l}4.1 \\
26\end{array}$ & $\begin{array}{r}4.1 \\
60\end{array}$ & $\begin{array}{r}4.2 \\
60\end{array}$ & $\begin{array}{l}4.2 \\
39\end{array}$ & 4.500 & & $\begin{array}{c}0, \\
01\end{array}$ & $\begin{array}{c}0, \\
02\end{array}$ & $\begin{array}{c}0, \\
00\end{array}$ & $\begin{array}{c}0, \\
06\end{array}$ \\
\hline 3 & $\begin{array}{l}\text { Purbaya } \\
\mathrm{ni}\end{array}$ & $\begin{array}{l}5.7 \\
18\end{array}$ & $\begin{array}{r}5.9 \\
10\end{array}$ & $\begin{array}{l}5.9 \\
11\end{array}$ & $\begin{array}{l}5.9 \\
11\end{array}$ & 5.917 & & $\begin{array}{c}0, \\
03\end{array}$ & $\begin{array}{c}0, \\
00\end{array}$ & $\begin{array}{c}0, \\
00\end{array}$ & $\begin{array}{c}0, \\
00\end{array}$ \\
\hline 4 & $\begin{array}{l}\text { Caringi } \\
\mathrm{n}\end{array}$ & $\begin{array}{l}5.8 \\
14\end{array}$ & $\begin{array}{c}5.8 \\
58\end{array}$ & $\begin{array}{l}5.8 \\
79\end{array}$ & $\begin{array}{l}5.9 \\
98\end{array}$ & 6.086 & & $\begin{array}{l}0, \\
01\end{array}$ & $\begin{array}{l}0, \\
00\end{array}$ & $\begin{array}{l}0, \\
02\end{array}$ & $\begin{array}{l}0, \\
01\end{array}$ \\
\hline 5 & $\begin{array}{l}\text { Sukara } \\
\text { me }\end{array}$ & $\begin{array}{r}7.5 \\
29\end{array}$ & $\begin{array}{r}8.0 \\
65\end{array}$ & $\begin{array}{l}8.1 \\
69\end{array}$ & $\begin{array}{r}7.9 \\
17\end{array}$ & 7.726 & & $\begin{array}{c}0, \\
07\end{array}$ & $\begin{array}{c}0, \\
01\end{array}$ & $\begin{array}{c}0, \\
03\end{array}$ & $\begin{array}{l}0, \\
02\end{array}$ \\
\hline 6 & $\begin{array}{l}\text { Samude } \\
\text { ra Jaya }\end{array}$ & $\begin{array}{c}3.8 \\
08\end{array}$ & $\begin{array}{r}4.0 \\
78\end{array}$ & $\begin{array}{r}4.0 \\
87\end{array}$ & $\begin{array}{r}4.0 \\
37\end{array}$ & 3.943 & & $\begin{array}{c}0, \\
07\end{array}$ & $\begin{array}{c}0 \\
00\end{array}$ & $\begin{array}{l}0, \\
01\end{array}$ & $\begin{array}{l}0, \\
02\end{array}$ \\
\hline & umlah & $\begin{array}{r}30 . \\
094\end{array}$ & $\begin{array}{r}31 . \\
387\end{array}$ & $\begin{array}{r}31 . \\
658\end{array}$ & $\begin{array}{r}31 . \\
422\end{array}$ & 31.894 & & $\begin{array}{c}0, \\
26\end{array}$ & $\begin{array}{c}0, \\
05\end{array}$ & $\begin{array}{c}0, \\
04\end{array}$ & $\begin{array}{c}0, \\
15\end{array}$ \\
\hline
\end{tabular}

\section{Proyeksi Penduduk}

Perencanaan suatu wilayah pada hakekatnya merupakan suatu upaya yang ditunjukkan untuk mewadahi kegiatan penduduknya. Kependudukan merupakan salah satu komponen yang penting dalam merencanakan suatu peran kota maupun wilayah. Dengan adanya kependudukan, maka perputaran arus barang dan arus uang akan menjadi lebih hidup. Hal ini juga yang menjadikan perkembangan kota atau wilayah menjadi lebih cepat. Proyeksi penduduk digunakan untuk memperkirakan jumlah penduduk masa mendatang. Jumlah penduduk proyeksi ini digunakan untuk merencanakan kebutuhan masyarakat Kecamatan Caringin, terutama untuk memenuhi kebutuhan fasilitas dan utilitas. Hasil dari jumlah penduduk proyeksi dapat digunakan untuk memperkirakan kondisi atau dampak di masa yang akan datang sehingga pemecahan permasalahan saat ini dan masa yang akan datang bisa dipersiapkan. Untuk lebih jelasnya mengenai analisis proyeksi penduduk dapat dilihat pada tabel 5.6 berikut ini.

Tabel 17

Proyeksi Penduduk

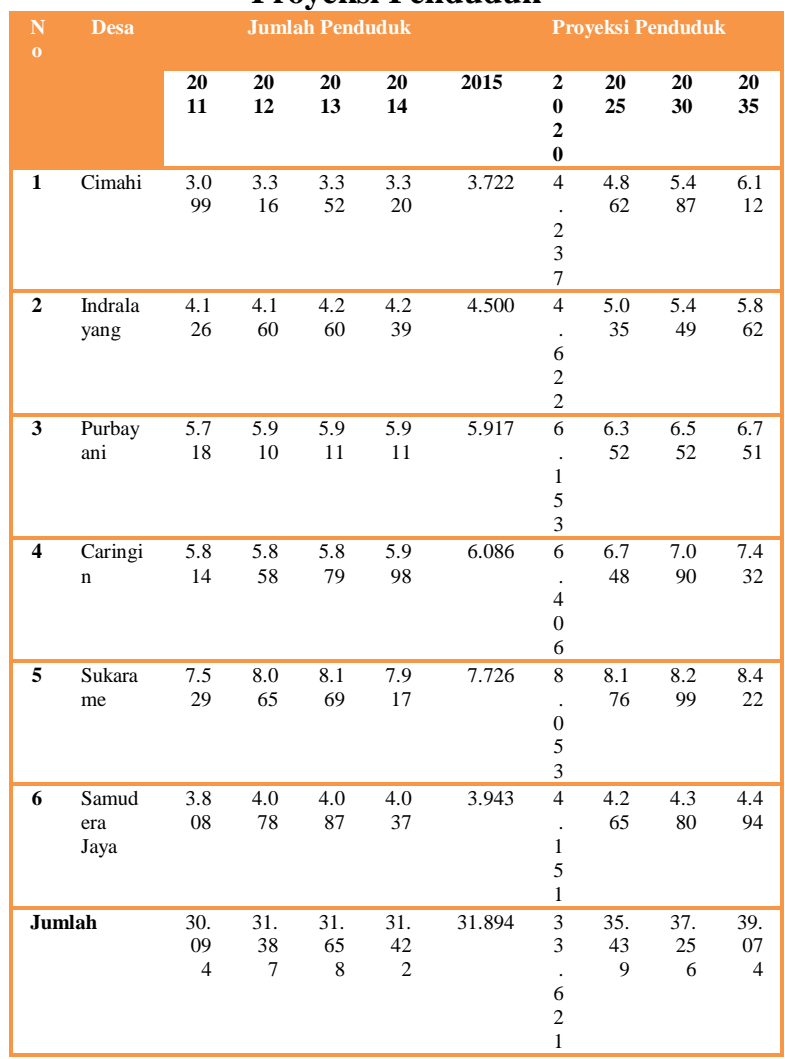

Dari tahun ke tahun analisis proyeksi jumlah penduduk ini mengalami pertambahan untuk tahun perencanaan 20 tahun kedepan untuk mempersipkan dampak yang akan terjadi dengan pertambahan jumlah penduduk tersebut 


\section{Kepadatan Penduduk}

Kepadatan penduduk dapat menunjukkan tingkat aktivitas suatu daerah. Analisa mengenai distribusi dan kepadatan penduduk sangat diperlukan untuk menciptakan pemerataan aktivitas sehingga populasi penduduk tidak membebani daerah tertentu saja. Adapun rumus kepadatan penduduk merupakan hasil pembagian antara jumlah penduduk (jiwa) dengan luas Kecamatan Caringin (Ha). Distribusi penduduk juga dapat sebagai usaha untuk mendukung pengembangan wilayah Kecamatan Caringin pada tahun 2020 hingga tahun 2035 dapat diproyeksikan seperti pada tabel dibawah. Dari hasil analisa didapatkan proyeksi pada 20 tahun yang akan dating. Kondisi Eksisting terakhir Kepadatan Penduduk yaitu pada tahun 2015 kawasan Kecamatan Caringin untuk total keseluruhan mencapai 16 jiwa/Ha. Untuk kepadatan perdesa penduduk paling padat terdapat di desa purbayani dan desa caringin yaitu 4 jiwa/Ha dan kepadatan terendah terdapat di desa Samudera jaya yaitu 1 jiwa/Ha. Untuk lebih jelasnya dapat diliat pada tabel 5.16 berikut ini.

\section{Tabel 18}

Kepadatan Penduduk

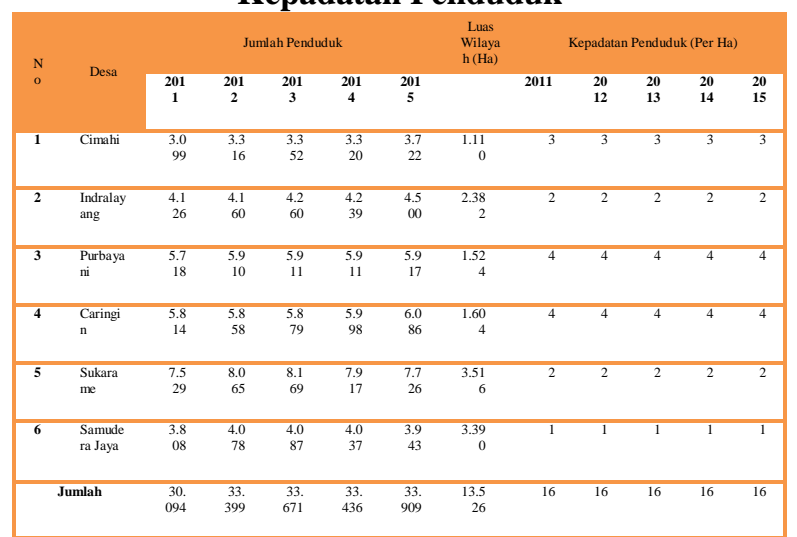

\section{b. Analisis Kebutuhan Rumah di Kecamatan} Caringin

Pembangunan perumahan merupakan faktor penting dalam peningkatan harkat dan martabat, mutu kehidupan serta kesejahteraan umum sehingga perlu dikembangkan secara terpadu, terarah, terencana serta berkelanjutan / berkesinambungan.
Tabel 19

Klasifikasi Kepadatan

\begin{tabular}{|lcccc|}
\hline \multicolumn{1}{|c}{ Klasifikasi Kawasan } & \multicolumn{3}{c|}{ Kepadatan } \\
& Rendah & Sedang & Tinggi & Sangat Padat \\
\hline Kepadatan Penduduk & $<150$ & $151-200$ & $201-400$ & $>400$ \\
& Jiwa/Ha & jiwa/Ha & jiwa/ha & jiwa/Ha \\
\hline Reduksi Terhadap Kebutuhan Lahan & & & $15 \%$ & $30 \%$ \\
& & & (Maksimal) & (Maksimal) \\
\hline
\end{tabular}

Sumber : Dokumen Petunjuk Perencanaan Kawasan Perumahan Kota.

Perkiraan kebutuhan permukiman di Kecamatan Caringin menggunakan pendekatan penyediaan perumahan berdasarkan jumlah penduduk di akhir tahun dengan perbandingan penyediaan perumahan berdasarkan tipe kecil: sedang: besar adalah 1:2:3. Rumah tipe kecil dengan luas $90 \mathrm{~m}^{2}$, tipe sedang $180 \mathrm{~m}^{2}$, dan tipe besar $360 \mathrm{~m}^{2}$, dengan asumsi 1 keluarga adalah 5 orang. Total kebutuhan rumah di Kawasan Pusat Pertumbuhan Rancabuaya pada akhir tahun perencanaan sebanyak 6724 unit. Untuk mengetahui lebih jelas perkiraan kebutuhan permukiman tahun 2034 dapat dilihat pada Tabel berikut.

Tabel 20

Analisis Kebutuhan Rumah di Kecamatan Caringin

\begin{tabular}{|c|c|c|c|c|c|c|c|}
\hline \multirow{3}{*}{$\begin{array}{l}\mathrm{N} \\
\mathrm{o}\end{array}$} & \multirow{3}{*}{ Desa } & \multirow{3}{*}{$\begin{array}{l}\text { Pendud } \\
\text { uk } \\
\text { (Jiwa) }\end{array}$} & \multirow{3}{*}{$\begin{array}{c}\text { Ruma } \\
\text { h } \\
\text { Tang } \\
\text { ga } \\
\text { (KK) }\end{array}$} & \multicolumn{3}{|c|}{$\begin{array}{c}\text { Perumahan (Unit) Tahun } \\
2034\end{array}$} & \multirow{3}{*}{$\begin{array}{c}\text { Total } \\
\text { Unit } \\
\text { Ruma } \\
\text { h }\end{array}$} \\
\hline & & & & Tipe A & $\begin{array}{c}\text { Tipe } \\
\text { B }\end{array}$ & Tipe & \\
\hline & & & & $60 \%$ & $30 \%$ & $10 \%$ & \\
\hline 1 & Cimahi & 4237 & 847.4 & 508.44 & 254 & 84.74 & 847 \\
\hline 2 & Indralayang & 4622 & 924.4 & 554.64 & 277 & 92.44 & 924 \\
\hline 3 & Purbayani & 6153 & $\begin{array}{r}1230 . \\
6 \\
\end{array}$ & 738.36 & 369 & $\begin{array}{r}123.0 \\
6 \\
\end{array}$ & 1231 \\
\hline 4 & Caringin & 6406 & $\begin{array}{r}1281 . \\
2 \\
\end{array}$ & 768.72 & 384 & $\begin{array}{r}128.1 \\
2 \\
\end{array}$ & 1281 \\
\hline 5 & Sukarame & 8053 & $\begin{array}{r}1610 . \\
6 \\
\end{array}$ & 966.36 & 483 & $\begin{array}{r}161.0 \\
6 \\
\end{array}$ & 1611 \\
\hline 6 & $\begin{array}{l}\text { Samudera } \\
\text { Jaya }\end{array}$ & 4151 & 830.2 & 498.12 & 249 & 83.02 & 830 \\
\hline & Jumlah & 33621 & $\begin{array}{r}6724 . \\
4\end{array}$ & 4034.64 & 2017 & $\begin{array}{r}672.4 \\
4\end{array}$ & 6724 \\
\hline
\end{tabular}

\section{c. Analisis Kebutuhan Air Bersih}

Air bersih merupakan salah satu kebutuhan utama masyarakat dimana air bersih ini banyak digunakan dalam kehidupan seharihari. Kecamatan Caringin merupakan suatu wilayah dengan masalah kesulitan air bersih pada sebagian wilayahnya. Hal ini mengartikan bahwa hampir keseluruhan wilayah Kecamatan Caringin belum terlayani air bersih yang pada umumnya disediakan oleh PDAM.

Berdasarkan permasalahan kesulitan air bersih yang melanda pada sebagian wilayah di Kecamatan Caringin, maka telah ditemukan 
pula sumber air yang terletak di Desa Sukarame dan mampu memenuhi kebutuhan air di Kecamatan Caringin. Untuk mengetahui kebutuhan air berdasarkan kondisi penduduknya, maka dilakukan perhitungan melalui rumus berikut :

1. Hitung kebutuhan air bersih dengan mengkalikan jumlah jiwa yang akan dilayani sesuai dengan tahun perencanaan (P) dikali dengan kebutuhan air perorang perhari $(q=60$ liter/jiwa/hari) dikali faktor hari maksismum $\left(\mathrm{f}_{\mathrm{md}}=1,05\right)$

$\mathrm{Q}=\mathrm{P} \times \mathrm{q}$

$\mathrm{Q}_{\mathrm{md}}=\mathrm{Q} \times \mathrm{f}_{\mathrm{md}}$

2. Hitung kebutuhan total air bersih (Qt), dengan faktor kehilangan air 20\% dengan persamaan :

$\mathrm{Qt}=\mathrm{Q}_{\mathrm{md}} \times$ 80/100

Berdasarkan perhitungan dengan menggunakan rumus diatas, maka kebutuhan air di Kecamatan Caringin pada tahun 20202035 dapat dilihat pada Tabel 5.1

\section{Tabel 21}

Hasil Analisis Kebutuhan Air Bersih di Kecamatan Caringin, Tahun 2020-2035

\begin{tabular}{|c|c|c|c|c|c|}
\hline \multirow{2}{*}{ No } & \multirow{2}{*}{ Desa } & \multicolumn{4}{|c|}{ Total Kebutuhan Air Bersih Lt/detik } \\
\hline & & 2020 & 2025 & 2030 & 2035 \\
\hline 1 & Cimahi & 5,10 & 5,85 & 6,6 & 7,36 \\
\hline 2 & Indralayang & 5,56 & 6,06 & 6,56 & 7,06 \\
\hline 3 & Purbayani & 7,41 & 7,65 & 7,89 & 8,13 \\
\hline 4 & Caringin & 7,71 & 8,12 & 8,53 & 8,95 \\
\hline 5 & Sukarame & 9,69 & 9,84 & 9,99 & 10,14 \\
\hline 6 & Samudera Jaya & 5 & 5,13 & 5,27 & 5,41 \\
\hline & Rata-rata & 6,75 & 7,11 & 7,47 & 7,84 \\
\hline
\end{tabular}

Pada Tabel didapatkan kebutuhan air bersih pada masing-masing desa dimana kebutuhan tertinggi terdapat di Desa Sukarame dengan kebutuhan air bersih sebesar 10,14 liter/detik pada tahun 2035 mengingat Desa Sukarame memiliki jumlah penduduk tertinggi dibandingkan dengan desa lainnya. Sedangkan kebutuhan air terendah terdapat di Desa Samudera Jaya yaitu sebesar 5,41 liter/detik pada tahun 2035 .

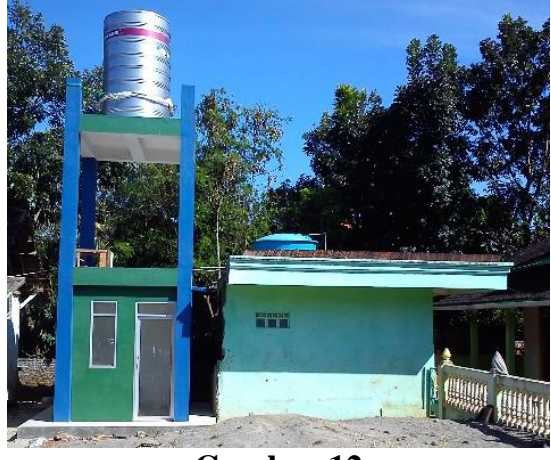

Gambar 12

Prasarana Air Milik Masyarakat Kecamatan Caringin

Perlu diketahui juga, selain mengandalkan pelayanan dari PDAM terdapat pula masyarakat yang memiliki fasilitas penampungan air pribadi (toren).

\section{d. Analisis Timbulan Limbah}

Limbah merupakan hasil buangan dari setiap aktivitas yang dilakukan manusia. Limbah terus menerus muncul seiring dengan berlangsungnya kegiatan manusia. Untuk mengetahui produksi limbah yang dihasilkan oleh manusia perharinya, dapat dihitung melalui rumus berikut ini :

1. Dihitung jumlah penduduk terlayani pelayanan limbah (80\% jumlah penduduk tahun eksisting)

2. Dari jumlah penduduk terlayani maka dihitung volume limbah domestik dimana produksi limbah/orang/hari adalah $\pm 7,69$ $\mathrm{m}^{3} /$ hari pada tahun 2035

Berdasarkan rumus perhitungan volume timbunan sampah, maka didapat volume limbah domestik di Kecamatan Caringin pada tahun 2020-2035 pada Tabel 5.18

Tabel 22

Hasil Analisis Volume Limbah Domestik di Kecamatan Caringin, Tahun 2020-2035

\begin{tabular}{|clcccc|}
\hline No & \multicolumn{1}{c}{ Desa } & $\mathbf{2 0 2 0}$ & $\mathbf{2 0 2 5}$ & $\mathbf{2 0 3 0}$ & $\mathbf{2 0 3 5}$ \\
\hline $\mathbf{1}$ & Cimahi & 5,00 & 5,74 & 6,48 & 7,22 \\
\hline $\mathbf{2}$ & Indralayang & 5,94 & 5,94 & 6,43 & 6,92 \\
\hline $\mathbf{3}$ & Purbayani & 7,50 & 7,50 & 7,73 & 7,97 \\
\hline $\mathbf{4}$ & Caringin & 7,97 & 7,97 & 8,37 & 8,77 \\
\hline $\mathbf{5}$ & Sukarame & 9,65 & 9,65 & 9,80 & 9,94 \\
\hline $\mathbf{6}$ & Samudera Jaya & 5,04 & 5,04 & 5,17 & 5,31 \\
\hline & Rata-rata & 6,85 & 6,97 & 7,33 & 7,69 \\
\hline
\end{tabular}




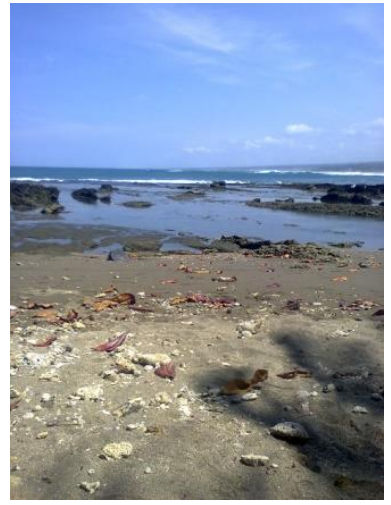

Gambar 13

Permasalahan Limbah di Kawasan Pantai Cidora Desa Purbayani

Sumber : Hasil Survey, 2013

Limbah adalah masalah yang terus menerus terjadi bagi masyarakat. Permasalahan limbah ini dapat dilihat di kawasan Pantai Cidora, Desa Purbayani dimana limbah yang berserakan mengganggu pemandangan dan keasrian pantai ini. Dalam mengatasi permasalahan limbah ini perlu dilakukan pengelolaan yang baik supaya limbah dapat terangkut pada tempat pembuangan akhir.

\section{e. Analisis Timbulan Sampah}

Sampah merupakan hasil pembuangan yang pasti muncul dikarenakan kegiatan manusia pula akan terus berlangsung. Sampah yang muncul setiap harinya berasal dari berbagai kegiatan. Hal ini memunculkan suatu hal yang perlu diketahui bahwa kegiatan yang berbeda akan menghasilkan volume sampah yang berbeda pula. Berdasarkan hal tersebut, timbulan sampah rata-rata adalah sebesar $19,54 \mathrm{~m}^{3} /$ hari. Berikut selengkapnya analisis timbulan sampah pada Kecamatan Caringin.

Tabel 22

Hasil Analisis Volume Limbah Domestik di Kecamatan Caringin,

Tahun 2020-2035

\begin{tabular}{|llcccc|}
\hline \multirow{2}{*}{ No } & \multicolumn{1}{c}{ Desa } & $\mathbf{2 0 2 0}$ & $\mathbf{2 0 2 5}$ & $\mathbf{2 0 3 0}$ & $\mathbf{2 0 3 5}$ \\
\hline $\mathbf{1}$ & Cimahi & 12,71 & 14,59 & 16,46 & 18,34 \\
\hline $\mathbf{2}$ & Indralayang & 13,86 & 15,11 & 15,93 & 17,59 \\
\hline $\mathbf{3}$ & Purbayani & 18,46 & 19,06 & 19,46 & 20,25 \\
\hline $\mathbf{4}$ & Caringin & 19,22 & 20,24 & 20,93 & 22,30 \\
\hline $\mathbf{5}$ & Sukarame & 24,16 & 24,53 & 24,78 & 25,27 \\
\hline $\mathbf{6}$ & Samudera Jaya & 12,45 & 12,80 & 13,03 & 13,48 \\
\hline & Rata-rata & 16,81 & 17,72 & 18,43 & 19,54 \\
\hline
\end{tabular}

Berdasarkan rencana pada tabel diatas, didapat bahwa timbulan sampah tertinggi muncul pada penggunaan lahan dengan fungsi jasa dan sarana pendidikan. Sedangkan timbulan sampah terendah muncul pada penggunaan lahan dengan fungsi perkantoran perdesaan.

\section{f. Analisis Kebutuhan Listrik}

Listrik adalah tenaga yang dibutuhkan manusia guna mengoperasikan berbagai fasilitas untuk menjalani kehidupannya. Kebutuhan listrik merupakan kebutuhan yang penting dimana listrik dapat membantu kehidupan manusia dalam hal pendidikan, ekonomi dan sebagainya. Dengan adanya pemenuhan kebutuhan listrik maka dapat memperlihatkan perkembangan sebuah wilayah. Asumsi kebutuhan listrik bagi masyarakat adalah $450 \quad$ VA/orang/hari. Berdasarkan asumsi tersebut, maka kebutuhan listrik bagi masyarakat di Kecamatan Caringin dapat dilihat pada Tabel 23

Tabel 23

Hasil Analisis Kebutuhan Listrik di Kecamatan Caringin, Tahun 2020-2035

\begin{tabular}{|cccccc|}
\hline No & Desa & \multicolumn{5}{c|}{ Kebutuhan Daya (KVA) } \\
& & $\mathbf{2 0 2 0}$ & $\mathbf{2 0 2 5}$ & $\mathbf{2 0 3 0}$ & $\mathbf{2 0 3 5}$ \\
\hline $\mathbf{1}$ & Cimahi & 763 & 875 & 988 & 1.100 \\
\hline $\mathbf{2}$ & Indralayang & 832 & 906 & 981 & 1.055 \\
\hline $\mathbf{3}$ & Purbayani & 1.107 & 1.143 & 1.179 & 1.215 \\
\hline $\mathbf{4}$ & Caringin & 1.153 & 1.215 & 1.276 & 1.338 \\
\hline $\mathbf{5}$ & Sukarame & 1.450 & 1.472 & 1.494 & 1.516 \\
\hline $\mathbf{6}$ & Samudera Jaya & 747 & 768 & 788 & 809 \\
\hline & Rata-rata & 1.009 & 1.063 & 1.118 & 1.172 \\
\hline
\end{tabular}

Kebutuhan listrik terus meningkat setiap tahunnya seiring dengan bertambahnya jumlah penduduk pada masing-masing desa. Kebutuhan tertinggi terdapat di Desa Sukarame dengan kebutuhan listrik perhari sebesar 1.516 KVA dan kebutuhan terendah terdapat di Desa Samudera Jaya dengan kebutuhan listrik perhari sebesar 809 KVA. Analisis jaringan prasarana jalan yang akan dipaparkan merupakan konsep yang menjadi ilustrasi dalam implementasi pengembangan dari masing-masing prasarana.

g. Jaringan Prasarana Jalan 
Jalan perumahan yang baik harus dapat memberikan rasa aman dan nyaman bagi pergerakan pejalan kaki, pengendara sepeda dan pengendara kendaraan bermotor.Selainitu harus didukung pula oleh ketersediaan prasarana pendukung jalan, seperti perkerasanjalan, trotoar, drainase, lansekap, rambu lalu lintas, parkir dan lain-lain.

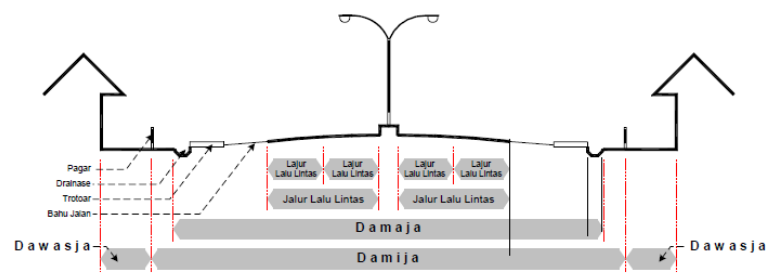

Gambar 14

Deskripsi Bagian Bagian Jalan

Sumber : SNI-03-1733-2004

Rencana pengembangan jaringan jalan di Kecamatan Caringin ditetapkan berdasarkan struktur ruang Kecamatan Caringin. Jalan yang akan dikembangkan di Kecamatan Caringin meliputi jalan lokal primer, jalan lokal sekunder dan jalan lingkungan. Pengembangan jalan ini harus disesuaikan dengan ketentuan geometri jalan yang ditentukan dalam standar nasional Indonesia.

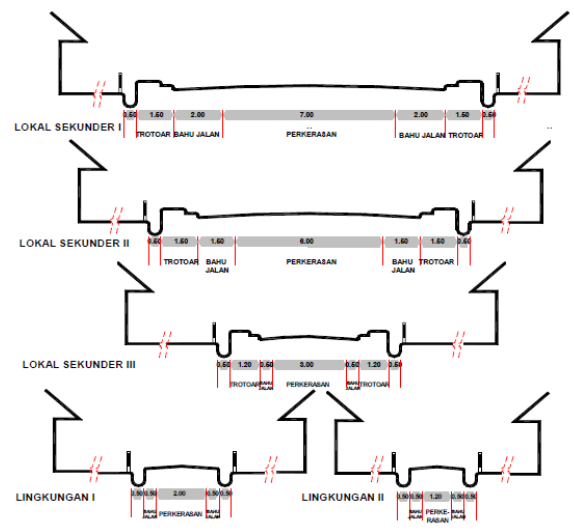

Gambar 15

Potongan Jalan Menurut Klasifikasi

Sumber : SNI-03-1733-2004

Berdasarkan potongan jalan pada gambar didapat bahwa potongan jalan terbagi kedalam bagian perkerasan, bahu jalan dan trotar. Setiap status jalan memiliki ukuran yang berbeda pada setiap potongannya. Hal ini menjadi dasar dalam pengembangan jalan di kawasan perkotaan meliputi kawasan pesisir perkotaan Kecamatan Caringin.

\section{Analisis Kemampuan Tumbuh dan Berkembang}

\section{Potensi dan Masalah Wilayah Perencanaan}

Potensi dan permasalahan di Kecamatan Caringin dipaparkan berdasarkan hasil survey dan observasi. Potensi yang ada tentunya mendukung pengembangan Kecamatan Caringin sebagai PKWp di Kabupaten Garut. Sedangkan permasalahan yang muncul perlu menjadi perhatian agar tidak menjadi hambatan pengembangan Kecamatan Caringin. Potensi dan masalah di Kecamatan Caringin dipaparkan melalui Gambar dibawah

\section{Kesimpulan}

Berdasarkan hasil analisis kebutuhan Prasarana dan analisis Kependudukan di Kecamatan Caringin maka dapat disimpulkan bahwa strategi yang akan digunakan adalah sebagai berikut :

1. Strategi untuk meningkatkan keterkaitan antar kawasan pusat pertumbuhan Rancabuaya dengan daerah lainnya, meliputi:

a. Mengembangkan pusat pariwisata bahari;

b. Meningkatkan fungsi dan status jalan antar pusat kawasan;

c. Menyediakan sarana dan prasarana pendukung fungsi pusat kawasan;

2. Strategi untuk meningkatkan daya tarik objek wisata di setiap satuan wilayah pengembangan agar dapat bersaing dengan objek wisata di daerah lain, meliputi:

a. Meningkatkan keterkaitan kawasan pariwisata dengan pusat kawasan pusat pertumbuhan Rancabuaya;

b. Mengembangkan prasarana dan sarana pendukung kegiatan pariwisata;

c. Mengembangkan pusat informasi dan promosi pariwisata.

3. Strategi untuk meningkatkan kualitas prasarana Kecamatan Caringin

a. Pengembangan Jaringan Air Bersih

Penyediaan air bersih di Kecamatan Caringin untuk masa yang akan datang perlu ditingkatkan diantaranya meliputi perluasan atau penyebaran sistem distribusi air minum terhadap 
kebutuhan pariwisata dan kebutuhan penduduk di kawasan Kecamatan Caringin dengan memasang pipa-pipa sesuai dengan permintaan sehingga dapat menjangkau seluruh kawasan tersebut. Pengembangan saluran

b. Pembuangan (Limbah)

Untuk pembuangan air kotor dan air hujan sebaiknya digunakan saluran terpisah dengan onsite-system, dimana air limbah ditampung dalam septik tank, dimana penguraian terjadi dengan cairannya diserap oleh tanah dan dibuang ke saluran pembuangan melalui sungai terdekat. Buangan air kotor dari rumah-ruah, fasilitasfasilitas pariwisata dan bangunan lainnya menggunakan saluran tertutup dan disalurkan pada saluran sekunder/tersier serta ke sungai terdekat.

c. Pengembangan jaringan listrik

Adapun penataan sistem jaringan listrik ini antara lain : untuk gardu distributor ditempatkan pada pusat fasilitas, hal ini agar memudahkan perbaikan apabila terjadi kerusakan ataupun ada gangguan aliran listrik, dan untuk tahun 2035 dibutuhkan daya rata-rata tiap desanya $1.172 \mathrm{KVA}$, untuk itu PLN Kabupaten garut harus meningkatkan daya untuk kebutuhan Kecamatan Caringin agar tidak terjadi kesenjangan antar wilayah. Sistem distribusinya menggunakan jaringan kabel tanah, hal ini dilakuka agar tidak mengganggu estetika kawasan. Pada kondisi eksisting jaringan sudah menjangkau di kawasan Kecamatan Caringin. Sistem jaringan listrik dalam pengembangannyadisesuaikan dengan permintaan konsumen/penduduk Kecamatan Caringin.

d. Pengembangan Jaringan Jalan

Pengembangan jaringan jalan disesuaikan dengan pola jaringan jalan yang sudah ada dan kecenderungan perkembangan fisik kawasan (Mengikuti Struktur Ruang Kawasan Kecamatan Caringin yang direncanakan). Jalan yang akan dikembangkan di Kecamatan Caringin meliputi jalan lokal primer, jalan lokal sekunder dan jalan lingkungan. Dimana yang dilakukan pengembangan peningkatan kualitas jalan dari tiap desa ke pusat kecamatan

\section{Daftar Pustaka}

Kabupaten Garut, 2000 RIPPDA Kabupaten Garut Tahun 2000 Tentang Rencana Induk Pengembangan Pariwisata Daerah Kabupaten Garut

KEPPRES NO. 32 Tentang Kawasan Lindung dan BudidayaRepublik Indonesia. 1990. UU No.9 Tahun 1990 Tentang Kepariwisataan 